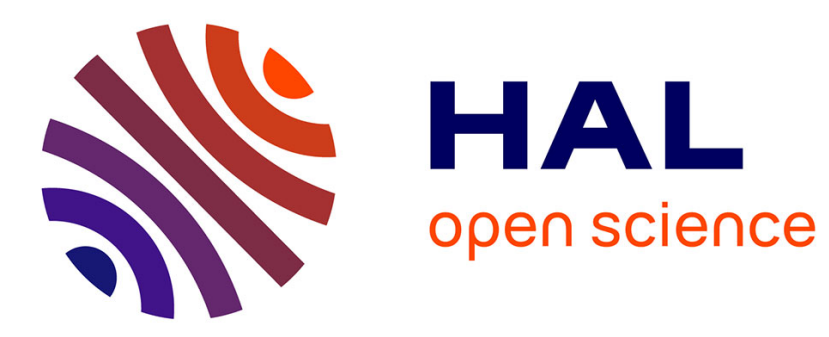

\title{
Intermolecular Rhodium-Catalysed Hydroamination of Non-Activated Olefins: Effect of Olefin, Amine, Phosphine and Phosphonium Salt
}

Mireia Rodriguez-Zubiri, Christine Baudequin, Aurélien Béthegnies, Jean-Jacques Brunet

\section{To cite this version:}

Mireia Rodriguez-Zubiri, Christine Baudequin, Aurélien Béthegnies, Jean-Jacques Brunet. Intermolecular Rhodium-Catalysed Hydroamination of Non-Activated Olefins: Effect of Olefin, Amine, Phosphine and Phosphonium Salt. ChemPlusChem, 2012, 77 (6), pp.445-454. 10.1002/cplu.201200017 . hal-01016806

\section{HAL Id: hal-01016806 https://hal.science/hal-01016806}

Submitted on 25 Mar 2021

HAL is a multi-disciplinary open access archive for the deposit and dissemination of scientific research documents, whether they are published or not. The documents may come from teaching and research institutions in France or abroad, or from public or private research centers.
L'archive ouverte pluridisciplinaire HAL, est destinée au dépôt et à la diffusion de documents scientifiques de niveau recherche, publiés ou non, émanant des établissements d'enseignement et de recherche français ou étrangers, des laboratoires publics ou privés. 
DOI: $10.1002 /$ cplu.201200017

Full Paper

M. Rodriguez-Zubiri et ${ }^{\wedge \wedge}$ al.

Rhodium Catalysis

Intermolecular Rhodium-Catalysed Hydroamination of Non-Activated Olefins: Effect of Olefin, Amine, Phosphine and Phosphonium Salt

Dr. Mireia Rodriguez-Zubiri, ${ }^{[a, b]}$ Dr. Christine Baudequin, ${ }^{[a, c]}$ Aurélien Béthegnies, ${ }^{[a]}$ and Dr. Jean-Jacques Brunet ${ }^{[\mathrm{a}]}$

[a] LCC (Laboratoire de Chimie de Coordination)

CNRS, Université de Toulouse, UPS, INPT

205, Route de Narbonne, 31077 Toulouse (France)

[b] Université de Nantes, UFR Sciences et Techniques

UMR CNRS 6230, CEISAM

2, Rue de la Houssinière, BP 92208, 44322 Nantes Cedex 3 (France)

Fax: $(+33)^{\wedge} 251-125-402$

E-mail: mireia.rodriguez@univ-nantes.fr

Present address: Université de Nantes

[c] Chimie Organique Bio-Organique Réactivité et Analyse

CNRS UMR 6014 and FR 3038

Université et Institut National des Sciences, Appliquées (INSA) de Rouen

Rue Tesnière, 76130 Mont-Saint-Aignan (France)

Present address: Université de Rouen

The right combination: $\mathrm{RhCl}_{3} \cdot 3 \mathrm{H}_{2} \mathrm{O} / \mathrm{P}\left(p-\mathrm{CH}_{3} \mathrm{C}_{6} \mathrm{H}_{4}\right)_{3} / n \mathrm{Bu}_{4} \mathrm{PI} / \mathrm{I}_{2}$ led to the highest catalytic activity for the intermolecular hydroamination of ethylene, 1-butene, and 1-hexene with aniline-type amines. Excellent activities were also found using $\mathrm{Rh}^{\mathrm{I}}$ Wilkinson's catalysts and the very efficient "in-situ generated" I ${ }^{<\mathrm{M}->}$ from $\mathrm{PPh}_{3} / \mathrm{I}_{2}$, which can substitute pre-synthesized $n \mathrm{Bu}_{4} \mathrm{PI}$ (see scheme; $\mathrm{CE}=$ catalytic efficiency). 
halides

hydroamination

non-activated alkenes

phosphines

rhodium

The catalytic system $\mathrm{RhCl}_{3} \cdot 3 \mathrm{H}_{2} \mathrm{O} / 2 \mathrm{P}\left(p-\mathrm{CH}_{3} \mathrm{C}_{6} \mathrm{H}_{4}\right)_{3} / 65 n \mathrm{Bu}_{4} \mathrm{PI} / 2 \mathrm{I}_{2}$, which was discovered recently in our research group, allows the highest catalytic activity ever reported for the intermolecular hydroamination of ethylene, 1-butene, and 1-hexene with aniline-type amines $\left(0.3^{\wedge \wedge} \mathrm{mol}^{\wedge} \%\right.$ catalytic precursor) to give the expected $N$-alkyl- $(N$-ethyl-, $\mathbf{1})$ and $N, N$-dialkylanilines ( $N, N$-diethyl-, 2), along with 2-methyl quinolines (3) (in the case of ethylene). The effects of time and temperature, as well as the nature of the phosphonium salt, phosphine, and amine on the catalytic activity of this reaction have been studied. This system is particularly efficient for the hydroamination of ethylene with aniline in the presence of 2,2'bis(diphenylphosphino)-1,1'-binaphthyl $\left(\mathrm{CE}^{*}=460\right)$ and tri( $p$-tolyl)phosphine $\left(\mathrm{CE}^{*}=520\right)$. Good to excellent activities were also found by combining Wilkinson's catalysts $\left(\mathrm{Rh}^{\mathrm{I}}\right.$ complexes) with $n \mathrm{Bu}_{4} \mathrm{PI}$ and $\mathrm{I}_{2}$. The simple association of $\mathrm{PPh}_{3}$ and $\mathrm{I}_{2}$ has been shown to be a very efficient "in-situ generated" source of $\mathrm{I}^{<\mathrm{M}->}$ promoters. ${ }^{*} \mathrm{CE}$ (catalytic efficiency) $=\mathrm{TON}_{1}+2 \mathrm{TON}_{2}+2 \mathrm{TON}_{3}$.

\section{Introduction}

Amines are important chemicals used in industry and in everyday life. ${ }^{[1, \wedge 2]}$ Chemists have developed many synthetic routes for the preparation of amines but most of them are not suitable for industrial purposes. ${ }^{[3]}$ Amines are mostly synthesised from alcohols by the process discovered in 1909 by Paul Sabatier. ${ }^{[4,5]}$ As alcohols are mainly obtained from alkenes either by hydration or by the hydroformylation/hydrogenation sequence, ${ }^{\left[6,{ }^{\wedge}\right]}$ the overall synthesis of amines requires two steps----the last step also produces water, which is an expensive and polluting side-product to be removed $\left(\right.$ Scheme $\left.e^{\wedge \wedge} 1<\operatorname{schr} 1>\right)$.

In this context, the direct transformation of olefins into amines (the hydroamination reaction; Scheme $\mathrm{A}^{\wedge} 2<\mathrm{schr} 2>$ ) is obviously an interesting economic and ecologic alternative. 
Nevertheless, this atom-economic reaction requires a catalytic process because such additions are characterised by a high activation barrier. ${ }^{[8]}$

Great improvements have been reported on the design of catalytic systems for the intramolecular hydroamination of alkenes and for the intermolecular hydroamination of unsaturated substrates such as alkynes, vinylarenes, dienes, and allenes, which are more reactive than simple alkenes. ${ }^{[9]}$ Indeed, the intermolecular hydroamination of non-activated alkenes is particularly challenging and remains the main challenge. ${ }^{\left[{ }^{\wedge} 10\right]}$

A few years ago our research group reported the discovery of an original $\mathrm{Pt}^{\mathrm{II}}$ system, $\mathrm{PtBr}_{2} / n \mathrm{Bu}_{4} \mathrm{PBr}$, which involves the association of simple $\mathrm{Pt}^{\mathrm{II}}$ salts with ionic liquids (phosphonium halides). It proved to be the first platinum-based system that allows the catalytic hydroamination of ethylene with anilines $\left[\mathrm{Eq} .{ }^{\wedge \wedge}(1)\right]$. Furthermore, the above association permits the catalytic hydroamination of higher alkenes, such as 1-hexene (still a remarkable result) with a surprisingly high Markovnikov regioselectivity $\left(>95^{\wedge} \%\right) .{ }^{[11]} \mathrm{A}$ breakthrough in this area was the discovery of such platinum-based systems that were equally effective in water using common salts such as $\mathrm{NaBr}$ instead of $n \mathrm{Bu}_{4} \mathrm{PBr}$ as the source of bromide ions. ${ }^{[12]}$

$<\mathrm{ZS}>(1)$

Aiming to improve the performance of this already efficient catalytic system, some mechanistic studies on the low-energy species of the catalytic cycle were carried out. The $\left[\mathrm{Pt}\left(\mathrm{C}_{2} \mathrm{H}_{4}\right) \mathrm{Br}_{3}\right]^{<\mathrm{M}->}$ complex was found to be the resting-state species. ${ }^{[13]}$

In view of previous results on the platinum-based catalytic systems, we were prompted to examine the possible activating effect of $n \mathrm{Bu}_{4} \mathrm{PX}$ derivatives on the rhodium(III)-catalysed hydroamination of ethylene with anilines. ${ }^{[14]}$ Literature data on rhodium-catalysed hydroamination reactions of ethylene and/or higher non-activated olefins are scarce and exemplify the challenges in achieving good catalytic activity for this reaction.

In 1971, Coulson first reported that $\mathrm{RhCl}_{3} \cdot 3 \mathrm{H}_{2} \mathrm{O}$ catalyses the hydroamination of ethylene under high-temperature $\left(180--200^{\wedge}{ }^{\circ} \mathrm{C}\right)$ and high-pressure $\left(50--140^{\wedge \wedge}\right.$ bar $)$ conditions. ${ }^{\left[15,{ }^{\wedge} 16\right]}$ Nevertheless, this reaction was restricted to ethylene and secondary amines 
of high basicity and low steric bulk (e.g. piperidine, $\left.\mathrm{p} K_{\mathrm{b}}=2.88\right)$. In contrast, Diamond et ${ }^{\wedge} \wedge \mathrm{a}$. reported that $\mathrm{RhCl}_{3} \cdot 3 \mathrm{H}_{2} \mathrm{O}$, associated with $\mathrm{PPh}_{3}\left(2^{\wedge \wedge}\right.$ equiv), catalyses the hydroamination of ethylene with aniline $\left(\mathrm{p} K_{\mathrm{b}}=9.37\right)$ at high temperatures. ${ }^{[17, \wedge 18]}$ Although catalytic activity was quite low, the main interest of their study was to show that this reaction afforded 2methylquinoline as a secondary, highly elaborated product. Later on, Taube et ${ }^{\wedge}$ al. studied the $\mathrm{Rh}^{\mathrm{III}}$ system reported by Coulson and concluded that it was limited because of decomposition of the active $\left[\mathrm{RhCl}\left(\mathrm{C}_{2} \mathrm{H}_{4}\right)\right.$ pip 2$]$ (pip=piperidine) species to yield metallic rhodium species. ${ }^{\left[19,{ }^{\wedge 20]}\right.}$ Taube and co-workers conceived a cationic rhodium(I) complex, $\left[\mathrm{Rh}\left(\mathrm{PPh}_{3}\right)_{2}\left(\mathrm{C}_{2} \mathrm{H}_{4}\right)\left(\mathrm{Me}_{2} \mathrm{CO}\right)\right] \mathrm{PF}_{6}$, which is active for the hydroamination of ethylene with piperidine at room temperature and at atmospheric pressure. Unfortunately, this system is completely deactivated within ten cycles. ${ }^{[20, \wedge 8 b]}$ These authors also reported relevant mechanistic investigations on a possible reaction pathway. ${ }^{[21]}$

Taking into account the state-of-the-art mentioned above, our results in this area are particularly interesting. Indeed, the association of the usual " $\mathrm{RhCl}_{3} \cdot 3 \mathrm{H}_{2} \mathrm{O} / 2 \mathrm{PPh}_{3}$ " catalytic precursor $\left(0.3^{\wedge \wedge} \mathrm{mol}^{\wedge} \%\right)$ with $n \mathrm{Bu}_{4} \mathrm{PI}\left(65^{\wedge \wedge}\right.$ equiv with respect to $\left.\mathrm{Rh}\right)$ and iodine $\left(2^{\wedge \wedge}\right.$ equiv with respect to $\mathrm{Rh}$ ) was found to be the most active catalytic system reported so far for the hydroamination of ethylene with aniline $\left[\mathrm{Eq} \cdot{ }^{\wedge \wedge}(2)\right] .^{[14]}$

$\langle\mathrm{ZS}>(2)$

This system proved particularly efficient for the hydroamination of ethylene with $\mathrm{N}$ ethylaniline $\left[\mathrm{Eq} .^{\wedge \wedge}(3)\right.$; turnover number $(\mathrm{TON})>260$ after $\left.24^{\wedge \wedge} \mathrm{h}\right]$ and even more active, under comparable conditions, than the platinum systems $\left(\mathrm{PtBr}_{2} / n \mathrm{Bu}_{4} \mathrm{PX}\right)$ previously developed in our group. ${ }^{[10--14]}$

$<\mathrm{ZS}>(3)$

In both cases, the halide ions (especially iodides for the rhodium catalyst) associated with the phosphonium salt promote a dramatic increase of the catalytic activity. Indeed, control experiments indicated that in the absence of $n \mathrm{Bu}_{4} \mathrm{PI}$ and $\mathrm{I}_{2}$, the $\mathrm{RhCl}_{3} \cdot 3 \mathrm{H}_{2} \mathrm{O} / 2 \mathrm{PPh}_{3}$ system allows only very low activity $(\mathrm{TON}<5)$ for the reaction of $\mathrm{N}$-ethylaniline with ethylene, in agreement with observations reported by Diamond $\mathrm{et}^{\wedge \wedge} \mathrm{al} .{ }^{[17, \wedge 18]}$ 
Herein, we report a relevant study on the use of phosphorus ligands as co-catalysts for the rhodium-catalysed intermolecular hydroamination of ethylene and higher olefins such as 1-butene and 1-hexene with aniline $\left(\mathrm{p} K_{\mathrm{b}}=9.37\right)$. This simple one-pot catalytic system does not need to operate under inert atmosphere and does not need laborious experimental procedures. The $\mathrm{Rh}^{\mathrm{III}} / \mathrm{phosphine} / n \mathrm{Bu}_{4} \mathrm{PI}$ catalytic system provides great possibilities for an asymmetric version of this reaction, an almost unexplored area of research to date. ${ }^{[22, \wedge 23]}$ Indeed, the only two literature reports on the asymmetric intermolecular hydroamination of non-activated alkenes are the unprecedented study reported by Widenhoefer and co-workers ${ }^{[22]}$ using chiral [AuCl(phosphine)] pre-catalysts for ethylene and 1-alkene hydroamination with cyclic ureas $\left(\mathrm{p} K_{\mathrm{b}}=13.86--14.17\right)$, and later on the study by Hultzsch and co-workers ${ }^{[23]}$ involved chiral catalysts based on rare-earth metals for the stereoselective addition of basic amines (benzylamine, $\mathrm{p} K_{\mathrm{b}}=4.66$ ) to non-activated alkenes.

It is therefore important to note that our contribution concerns widely available amines, higher $\alpha$-olefins, and low loading $\left(0.3^{\wedge \wedge} \mathrm{mol}^{\wedge} \%\right)$ of a stable "one-pot" ready-to-use metal--ligand catalyst precursor. Furthermore, we were able to generate an "in situ" source of $\mathrm{I}^{<\mathrm{M}->}$ promoters and to show that this catalytic system is also efficient using $\mathrm{Rh}^{\mathrm{I}}$ complexes.

\section{Results and Discussion}

In this study, we were led to consider both the TON (moles of product formed by mole of catalyst used) and the catalytic efficiency (CE). The CEwas calculated on the basis of the number of cycles needed by the catalyst to yield each product (two cycles for the product of double hydroamination, 2, and for quinaldine, $\mathbf{3})^{[11 \mathrm{a}]}\left[\mathrm{Eqs.}^{\wedge \wedge}(2)\right.$ and (3)].

\section{Hydroamination of ethylene by aniline: influence of the phosphine ligand}

Our first experiments were aimed at investigating the effect of the relative amount of $\mathrm{PPh}_{3}$, an important parameter that was not extensively studied in our previous Communication $^{[14]}$ where we intended to test the experimental and analytical conditions (experimental details as in ref. ${ }^{\wedge}<\operatorname{litrsn}><\operatorname{litr11}><$ litr_c $></$ litrsn $>$ ) with regards to those reported earlier by Diamond et ${ }^{\wedge \wedge} \mathrm{al} .{ }^{\left[17,{ }^{\wedge 18]}\right.}$ for the hydroamination of ethylene with aniline. Using $2^{\wedge \wedge}$ equivalents of $\mathrm{PPh}_{3}$, we supposed the active catalytic species to contain the 
$\left\{\mathrm{RhI}\left(\mathrm{PPh}_{3}\right)_{2}\right\}$ moiety necessary for either the coordination of the alkene followed by the external nucleophilic addition of the starting amine, or the $\mathrm{N}<\mathrm{C}->\mathrm{H}$ oxidative addition and subsequent insertion of the alkene moiety. ${ }^{[8 \mathrm{~b}]}$

Typically, catalytic runs conducted with variable amounts of $\mathrm{PPh}_{3}\left(\mathrm{Table}^{\wedge \wedge} 1\right.$, entries $\left.^{\wedge \wedge} 1--6\right)$ confirmed that, indeed, the best results are obtained with either a $\mathrm{PPh}_{3} / \mathrm{Rh}$ ratio of 2 or 3. Either lower or higher amounts of phosphine resulted in a drop of the catalytic activity in part because of a lower conversion of $\mathbf{1}$ into $\mathbf{2}$. These results suggest that the addition of PhNHEt to ethylene is favoured in the presence of $I_{2}$ and is more sensitive to the $\mathrm{PPh}_{3} / \mathrm{Rh}$ ratio than in the case of $\mathrm{PhNH}_{2}$.

The influence of the nature of several phosphorus ligands was examined. Different types of phosphorus ligands containing alkyl, aryl, or alkoxy substituents were used and the results are listed in Table ${ }^{\wedge} 2$. In contrast with previous results on the platinum(II)-catalysed reactions of aniline with ethylene, ${ }^{[24]}$ where phosphorus ligands (to the exception of trialkylphosphites) seemed to act as inhibitors, $\mathrm{PPh}_{3}$ allows much better catalytic activity than trialkylphosphites (Table^^2, entries^^3--7). Aryloxy-substituted ligands (triaryl phosphites) and trialkylphosphines mediate the reaction but are inefficient co-catalysts (Table ${ }^{\wedge \wedge} 2$, entries $^{\wedge} 1,2$, and 8--11). In sharp contrast, the catalytic activity is partially recovered upon the introduction of phenyl groups as substituents of the phosphorus atoms as shown by the results obtained with mixed phosphorus ligands such as $\mathrm{P}(\mathrm{OMe}) \mathrm{Ph}_{2}$ and dppe (1,2bis(diphenylphosphino)ethane; Table ${ }^{\wedge \wedge} 2$, entries ${ }^{\wedge \wedge} 12$ and 13) where the $\mathrm{P}$ atom contains two phenyl substituents. Interestingly, excellent activities were obtained in the presence of binap (2,2'-bis(diphenylphosphino)-1,1'-binaphthyl; Table ${ }^{\wedge \wedge} 2$, entries ${ }^{\wedge \wedge} 14$ and 15), probably owing to the presence of three phenyl substituents on each $\mathrm{P}$ atom to create a quite similar electronic and steric environment when compared to $\mathrm{PPh}_{3}\left(1^{\wedge}\right.$ equiv of binap corresponds to $2^{\wedge \wedge}$ equiv of $\mathrm{P}$, which is analogous to the use of $2^{\wedge \wedge}$ equiv of $\mathrm{PPh}_{3}$ with respect to $\mathrm{Rh}$ ). Thus, it was concluded that the presence of phenyl groups in the structure of the phosphorus ligands is a key factor for achieving good catalytic activity.

Next, the electronic effects of the substituents on the phenyl groups of the triarylphosphines $\left(\right.$ Table ${ }^{\wedge} 2$, entries $\left.{ }^{\wedge \wedge} 16--18\right)$ were considered. We found that the 
$p a r a^{\wedge \wedge}$ substitution on the aryl ring with the strongly electron-withdrawing $\mathrm{CF}_{3}$ group dramatically lowers the catalytic activity. In a minor way, the $p$-OMe group (mesomeric electron-donating and inductive electron-withdrawing) also causes a loss of activity. In sharp contrast, the para inductive electron-donating $\mathrm{CH}_{3}$ substituent induces an important increase of the catalytic activity: this is in fact the best result ever reported for the intermolecular hydroamination of a non-activated olefin by aniline $\left(\mathrm{CE}=528\right.$; Table $\mathrm{e}^{\wedge} 2$, entry^^17).

In any case, formation of quinaldine $\mathbf{3}$ seems favoured when production of $\mathbf{1}$ is not, thus suggesting, once more, that $\mathbf{1}$ is not an intermediate in the pathway leading to $3{ }^{[14]}$ These results are of special importance when considering the enantioselective version of the intermolecular hydroamination of non-activated olefins (see introduction). These related studies are in progress within our group.

\section{Hydroamination of ethylene by aniline: influence of the amine}

To potentially widen the scope of this catalytic process, the addition of other primary and secondary amines to ethylene was studied. Hence, the efficiency for the hydroamination of ethylene with more basic amines was considered (Table^^3). Using $N$-ethylaniline, the catalytic system afforded $N, N$-diethylaniline as the only reaction product $\left[\mathrm{Eq} \cdot{ }^{\wedge \wedge}(3)\right]$ with higher TON than when the reaction was performed with aniline (Table^^3, entries $\left.{ }^{\wedge \wedge} 1--3\right)$.

On the other hand, morpholine $\left[\mathrm{Eq} \cdot{ }^{\wedge \wedge}(4)\right]$ and piperidine $\left[\mathrm{Eq} \cdot{ }^{\wedge \wedge}(5)\right]$, two more-basic non-aromatic amines, afforded very low catalytic activities (Table ${ }^{\wedge \wedge} 3$ entries $\mathrm{s}^{\wedge \wedge 5}$ and 6 ), possibly owing to strong coordination to the metal centre

$$
<\mathrm{ZS}>(4)
$$

$<\mathrm{ZS}>(5)$

Further experiments (Table 3, entry 4) showed an interesting result when performing the hydroamination of ethylene with benzylamine $\left[\mathrm{Eq} \cdot{ }^{\wedge \wedge}(6)\right]$. Indeed, as may be seen in Table^^3, the catalytic efficiency of this reaction does not depend on the $\mathrm{p} K_{\mathrm{b}} \wedge^{\wedge}$ value of the amine because morpholine and piperidine afford very low catalytic activities when compared to benzylamine, an amine with an intermediate $\mathrm{p} K_{\mathrm{b}}{ }^{\wedge \wedge}$ value. Analogously, the amine 
substitution does not seem to be a determining parameter by itself because aniline and benzylamine, two primary amines, allowed very different catalytic performance. The only structural factor that could somehow explain this result is perhaps, once more, related to the presence of an aryl group near to the nitrogen atom: for aniline and $N$-ethylaniline, the $\mathrm{N}$ atom is directly bonded to a $\operatorname{Csp}^{2 \wedge \wedge}$ atom and for the benzylamine, only one $\operatorname{Csp}^{3 \wedge \wedge}$ atom separates the $\mathrm{N}$ atom from the aryl $\mathrm{Csp}^{2} \wedge \wedge$ atom. Further studies (catalytic tests and theoretical calculations) are ongoing in our team to elucidate the parameters (nucleophicity, basicity, and/or steric hindrance) that influence the catalytic performance as a function of the nature of the starting amine.

$<\mathrm{ZS}>(6)$

\section{Hydroamination of ethylene by aniline: influence of the phosphonium salt}

On the basis of the excellent catalytic results obtained with the association of $n \mathrm{Bu}_{4} \mathrm{PI}$ with $\mathrm{PPh}_{3}$, we were prompted to evaluate the influence of the nature of the cation of the ionic salts, as we had done previously with the anion. ${ }^{[14]}$ For this purpose, catalytic runs were conducted in the presence of $\mathrm{Ph}_{4} \mathrm{PI}$, a phosphonium salt containing phenyl substituents on the $\mathrm{P}$ atom as in the case of the efficient $\mathrm{PPh}_{3}$ ligand, and $n \mathrm{Bu}_{4} \mathrm{NI}$, an ammonium salts with the same $n \mathrm{Bu}$ groups as our previous phosphonium candidate (Table $\left.{ }^{\wedge} 4\right)$. Surprisingly, association of the $\mathrm{RhCl}_{3} \cdot 3 \mathrm{H}_{2} \mathrm{O}$ catalyst with $\mathrm{Ph}_{4} \mathrm{PI}$ inhibited the efficiency of the reaction even in the presence of $\mathrm{PPh}_{3}\left(\mathrm{Table}^{\wedge \wedge} 4\right.$, entries $\left.{ }^{\wedge \wedge} 1--4\right)$, showing that the $\mathrm{PPh}_{4}{ }^{+}$counter cation must also have a role on the reactivity Physical properties of this salt, such as its high melting point $\left(338^{\wedge} \mathrm{C}\right)$, are not, $\mathrm{a}^{\wedge \wedge}$ priori, responsible for its catalytic behaviour because $\mathrm{Ph}_{4} \mathrm{PI}$ is soluble in aniline even at room temperature and thus able to react under the catalytic conditions $\left(150^{\wedge} \mathrm{C}\right)$.

In the same way, $n \mathrm{Bu}_{4} \mathrm{NI}$, strongly decreased the catalytic activity (Table ${ }^{\wedge \wedge} 4$, entry^^5) in the presence of $\mathrm{PPh}_{3}$ and $\mathrm{I}_{2}$, thus confirming our previously stated hypothesis on the relevance of the cation moiety of the promoter salt used.

Hydroamination of ethylene by aniline: "in-situ generated" source of $I^{<M->}$ promoters 
The rhodium-catalysed hydroamination reaction was tested in the presence of $\mathrm{PPh}_{3}$ and $\mathrm{I}_{2}$ (Table^^5). Our aim was to form "in situ" an ionic liquid similar to the one used previously $\left(n \mathrm{Bu}_{4} \mathrm{PI}\right)$, and to avoid in this way its synthesis, purification, and conditioning (see the Experimental Section). This idea was based on literature data that have proved the formation of the corresponding phosphonium salts when reacting a phosphine with $\mathrm{X}_{2}$ $\left(\right.$ Scheme $\left.{ }^{\wedge \wedge} 3<\operatorname{schr} 3>\right){ }^{[25]}$

Good results were obtained when using stoichiometric quantities of $\mathrm{PPh}_{3}$ and $\mathrm{I}_{2}$, with an optimum at $10^{\wedge \wedge}$ equivalents of each (Table^^5, entries^^2--4 and 6). Moreover, only $5^{\wedge \wedge}$ equivalents of each (Table ${ }^{\wedge} 5$, entry^^2), $\mathrm{PPh}_{3}$ and $\mathrm{I}_{2}$, afforded a better catalytic performance than the use of $20^{\wedge \wedge}$ equivalents of $n \mathrm{Bu}_{4} \mathrm{PI}\left(\mathrm{TON}_{1}=73, \mathrm{TON}_{2}=6, \mathrm{TON}_{3}=0\right.$, $\mathrm{CE}=85){ }^{[14]}$

\section{Hydroamination of ethylene by aniline: influence of temperature and reaction time}

Studies on the rhodium(III)-based catalytic systems were initially conducted at $150^{\wedge} \mathrm{C}$ because previous studies on the platinum(II)-catalysed addition of $\mathrm{PhNH}_{2}$ to ethylene had shown that this temperature seemed a good compromise between activity and energetic input. ${ }^{[26]}$ We wished then to explore the performance of this catalytic reaction under "milder" conditions to determine whether the catalytic efficiency could remain reasonably high in view of chiral processes. As may be seen in Table ${ }^{\wedge} 6$, catalytic activity drops dramatically when the temperature of the reaction was decreased from $150^{\wedge} \mathrm{C}$ to $125^{\wedge}{ }^{\circ} \mathrm{C}$ or $100^{\wedge} \mathrm{C}$. As already stated, ${ }^{[11 \mathrm{c}]}$ a possible explanation for this phenomena is as follows: because the reaction of aniline with ethylene coordinated to a transition-metal complex is disfavoured by the low nucleophilicity of aniline, the catalytic hydroamination is possible under high-temperature conditions to allow the zwitterionic addition complex $\left(\right.$ Scheme $\left.{ }^{\wedge \wedge} 4<\operatorname{schr} 4>\right)$ to experience a temperature-promoted cleavage of the carbon--metal bond, and thus displacing all the steps of the reaction to the formation of $N$-ethylaniline. ${ }^{[11 b]}$

In the same way, it was observed that an increase of the ethylene pressure from $25^{\wedge \wedge}$ bar to $45^{\wedge \wedge}$ bar has a negative effect on the TON of the reaction. This outcome is in contrast with previous results on the optimisation of the platinum(II)-catalysed 
hydroamination of ethylene by aniline where catalytic activity was promoted in the presence of higher amounts of either of the substrates (aniline/Pt and/or ethylene/Pt). ${ }^{[26]}$

Another important parameter to be studied was the evolution of the reaction with time. Hence, various experiments were carried out under the usual conditions for $10^{\wedge \wedge}$ hours and $93^{\wedge \wedge}$ hours. The results are collected in Table ${ }^{\wedge \wedge} 7$. As may be seen, after $10^{\wedge \wedge}$ hours of reaction $\left(\right.$ Table $^{\wedge \wedge} 7$, entry $\left.{ }^{\wedge \wedge} 1\right)$, the three hydroamination products were formed, although only small amounts of $\mathbf{2}$ and $\mathbf{3}$ were observed. The proportions are 19:2:1 for 1/2/3. On the other hand, after $93^{\wedge \wedge}$ hours of reaction (Table $\wedge^{\wedge} 7$, entry ${ }^{\wedge} 2$ ), the main product was $\mathbf{2}$, small amounts of $\mathbf{1}$ were detected compared to $\mathbf{2}$, and the amount of $\mathbf{3}$ did not increase after $10^{\wedge \wedge}$ hours of reaction. This outcome is consistent with the idea that $N, N$-diethylaniline is the product of a second hydroamination cycle where $N$-ethylaniline is added to ethylene. Thus, along the course of the reaction, the amount of $\mathbf{1}$ increase and, at the same time, $\mathbf{1}$ is transformed into $\mathbf{2}$. The proportions are 9:75:1 for $\mathbf{1 / 2} / \mathbf{3}$ after $93^{\wedge} \wedge$ hours of reaction.

As shown by the results stated in Table ${ }^{\wedge} 7$, as the reaction evolves, amounts of $\mathbf{2}$ increase whereas $\mathbf{1}$ is consumed thus suggesting that hydroamination of ethylene by more basic anilines such as $\mathbf{1}$, is favoured. Amounts of the quinoline derivative $\mathbf{3}$ remained unchanged after more than $80^{\wedge \wedge}$ hours, thereby confirming once more that $\mathbf{1}$ is probably not an intermediate in the pathway leading to $\mathbf{3}$.

\section{Hydroamination of higher $\alpha$-olefins by aniline}

The next step in our study was to use the $\mathrm{Rh}^{\mathrm{III}}$ precursors to explore the intermolecular hydroamination of higher non-activated $\alpha$-olefins such as 1-butene and 1-hexene. The products resulting from these reactions are of great relevance in industry and the reaction of higher $\alpha$-olefins is itself an important scientific challenge. ${ }^{\left[1,^{\wedge} 18, \wedge 27\right]}$ Literature on the intermolecular hydroamination of 1-butene and higher $\alpha$-olefins by simple amines is scarce, and only recently reported. Although catalytic activities were quite low when using organolanthanide complexes, Marks and co-workers ${ }^{[28, \wedge 9 \mathrm{Br}]}$ successfully achieved the hydroamination of 1-pentene with $n$-propylamine, under anaerobic conditions, at $60^{\wedge} \mathrm{C}^{\circ}$, using $20^{\wedge} \mathrm{mol} \%$ of the metal catalyst. These authors reported to deal with a challenging reaction, the intermolecular hydroamination of non-activated alkenes, in comparison to intramolecular 
hydroamination, 350x faster, and alkyne hydroamination, 1400x faster. In 2006, He and coworkers studied the addition of $\mathrm{TsNH}_{2}$ to 1 -octene with $5^{\wedge \wedge} \mathrm{mol}^{\wedge} \%$ of $\left[\mathrm{AuCl}\left(\mathrm{PPh}_{3}\right)\right] / \mathrm{AgOTf}$ in toluene at $85^{\wedge}{ }^{\circ} \mathrm{C}{ }^{[29 a]}$ In 2007 , Loh and co-workers studied the same reaction in the presence of $\operatorname{InBr}_{3}\left(20^{\wedge \wedge} \mathrm{mol}^{\wedge} \%\right)$ in toluene at $120^{\wedge}{ }^{\circ} \mathrm{C} .{ }^{[29 \mathrm{~b}]}$ Both research groups obtained the desired Markovnikov hydroamination product along with another Markovnikov isomer resulting from the hydroamination of an internal alkene formed by isomerisation of the initial terminal double bond. ${ }^{[29]}$ Later on, Loh and Yin found that lanthanide salts in ionic solvents $\left(2^{\wedge \wedge} \mathrm{mol}^{\wedge} \%\right.$ of $\left.\operatorname{Pr}(\mathrm{OTf})_{3}+n \mathrm{Bu}_{4} \mathrm{PI}+\mathrm{I}_{2}\right)$ catalysed the hydroamination of 1-heptene and 1octene with aniline, at $160^{\wedge}{ }^{\circ} \mathrm{C}$, with up to $95^{\wedge} \%$ of the Markovnikov addition products. ${ }^{[30]}$ They reported the use of phosphonium salts as we had previously described in two unprecedented reports on the hydroamination of 1-hexene by aniline in the presence of a ligandless, inexpensive, and non-toxic $\mathrm{PtBr}_{2} / n \mathrm{Bu}_{4} \mathrm{PBr} / \mathrm{H}^{+}$catalyst, at $150^{\wedge}{ }^{\circ} \mathrm{C}$, leading to $95^{\wedge} \%$ of the Markovnikov product without alkene isomerisation and with TON up to $200 .{ }^{\left[11 \mathrm{c},{ }^{\wedge 31]} \text { In }\right.}$ 2010, Hultzsch and co-workers ${ }^{[23]}$ succeeded in the use of sensitive rare-earth-metal asymmetric complexes $\left(5^{\wedge \wedge} \mathrm{mol}^{\wedge} \%\right)$ in toluene for the addition of simple amines to 1 -alkenes at $150^{\wedge} \mathrm{C}$, with good conversions and moderate $e e^{\wedge \wedge}$ values. Finally, Michon, AgbossouNiedercorn, and co-workers succeeded in the combined use of a copper halide $\left(5^{\wedge \wedge} \mathrm{mol}^{\wedge} \%\right)$ and a silver salt $\left(5--10^{\wedge \wedge} \mathrm{mol}^{\wedge} \%\right)$ for the hydroamination of 1-hexene by $\mathrm{TsNH}_{2}$ at $100^{\wedge}{ }^{\circ} \mathrm{C}$ to yield the Markovnikov isomers ( $N$-2- and $N$-3-hexylamines) in a ratio 4:6. ${ }^{[32]}$

No studies have been reported using rhodium-based catalytic systems----a fact that led us to test our $\mathrm{RhCl}_{3} \cdot 3 \mathrm{H}_{2} \mathrm{O} / n \mathrm{Bu}_{4} \mathrm{PI} / \mathrm{PPh}_{3} / \mathrm{I}_{2}$ system, which has turned out to be the best to date for the hydroamination of ethylene by simple amines. Thus, the addition of aniline to 1-butene

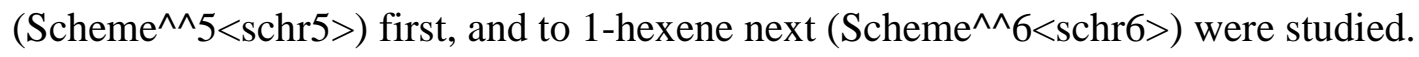

Our results in this area are particularly promising. In fact, this system is also an efficient catalyst for the hydroamination of 1-butene with up to $150^{\wedge \wedge} \mathrm{TON}$ (Table ${ }^{\wedge \wedge} 8$, entry $^{\wedge} 6$ ), and similar effects to the case of ethylene. Actually, the reaction of aniline with 1butene in the presence of the above rhodium(III)-based catalyst afforded the expected hydroamination butylanilines products, with a single Markovnikov isomer being highly predominant $\left(99^{\wedge} \%\right)$. Thus, the regioselectivity of this reaction appears even higher than for 
the $\mathrm{PtBr}_{2} / n \mathrm{Bu}_{4} \mathrm{PBr}$ system, for which a 95:5 Markovnikov/anti-Markovnikov ratio (M/AM) was observed. ${ }^{[11 \mathrm{~b}]}$ This is a significant result when thinking about applying this catalytic system to the enantioselective version of this reaction.

As no dibutylaniline compounds were detected after the reaction, it seems that, under our experimental conditions, a second hydroamination reaction of 1-butene by $N$-secbutylaniline does not proceed, possibly owing to steric effects. In the same way, no quinoline product from an aromatic $\mathrm{C}<\mathrm{C}->\mathrm{H}$ activation was observed. An overview of the results stated in Table $\wedge^{\wedge} 8$ reveals that for the addition of aniline to 1-butene, the precursor $\mathrm{RhCl}_{3} \cdot 3 \mathrm{H}_{2} \mathrm{O}$ is not active by itself (Table^^ 8 , entry^^1), thus confirming the work done by Coulson on the hydroamination reactions catalysed by the same precursor, where the catalyst showed activity only for the reaction of ethylene with basic amines. ${ }^{\left[15,{ }^{\wedge} 16\right]}$ In the presence of the phosphonium salts, moderate activities were observed (Table^^^, entries ${ }^{\wedge \wedge} 2$ and 3 ), especially with the $n \mathrm{Bu}_{4} \mathrm{PI}$ salt as was the case for the hydroamination of ethylene. ${ }^{[14]}$ Additionally, $\mathrm{PPh}_{3}$ and $\mathrm{I}_{2}$, in the absence of phosphonium salts, led to low activity (Table ${ }^{\wedge} 8$, entry $\left.{ }^{\wedge \wedge} 4\right)$, with a higher promoting effect than $n \mathrm{Bu} 4 \mathrm{PBr}$, but lower than the effect of $n \mathrm{Bu}_{4} \mathrm{PI}$. An increase of the activity is once more observed when both promoters, $n \mathrm{Bu}_{4} \mathrm{PI}$ and $\mathrm{PPh}_{3}$, are present $\left(\mathrm{Table}^{\wedge \wedge} 8\right.$, entry^^$^{\wedge}$ ), as was reported for the ethylene hydroamination with the same catalytic system. ${ }^{[14]}$ Results are improved by the addition of molecular iodine (Table ${ }^{\wedge} 8$, entries ${ }^{\wedge \wedge} 6$ and 7 ), with an optimum at $65^{\wedge \wedge}$ equivalents of $n \mathrm{Bu}_{4} \mathrm{PI}$.

The results in Table^^ 8 show that the $\mathrm{RhCl}_{3} \cdot 3 \mathrm{H}_{2} \mathrm{O} / n \mathrm{Bu}_{4} \mathrm{PI} / \mathrm{PPh}_{3} / \mathrm{I}_{2}$ system appears to be a highly selective catalyst for the hydroamination of higher olefins such as 1-butene by anilines, thus affording approximately a quarter of the catalytic activity reached for the same process with ethylene.

Concerning the hydroamination of 1 -hexene $\left(\right.$ Scheme $\left.^{\wedge \wedge} 6\right)$, preliminary results using the optimised conditions obtained for the reactions of ethylene and 1-butene in the presence of the $\mathrm{RhCl}_{3} \cdot 3 \mathrm{H}_{2} \mathrm{O} / n \mathrm{Bu}_{4} \mathrm{PI} / \mathrm{PPh}_{3} / \mathrm{I}_{2}$ catalytic system, have shown (Table^^9) the catalyst to achieve only one catalytic cycle in the absence of phosphonium salt (Table ${ }^{\wedge \wedge}$, entry $\left.{ }^{\wedge \wedge} 3\right)$. Nevertheless, the catalytic activity is recovered in the presence of $n \mathrm{Bu}_{4} \mathrm{PI}\left(150^{\wedge \wedge}\right.$ equiv; Table ${ }^{\wedge} 9$, entry^^2). More importantly, the very high regioselectivity obtained, $100^{\wedge} \%$ for the 
Markovnikov product, $\mathbf{8}$, with neither traces of the anti-Markovnikov isomer, 10, nor of quinoline derivatives. This is an important feature when compared to literature data where a great difference of regioselectivity between the (stoichiometric) hydroamination of propene (100^\% Markovnikov) and 1-hexene (46^\% Markovnikov, 54^\% anti-Markovnikov) was reported using $\left[\right.$ cis- $\mathrm{PtCl}_{2}\left(\mathrm{PR}_{3}\right)$ (olefin)] catalysts. ${ }^{[33]}$

On the other hand, a significant amount of a secondary Markovnikov isomer (N-3hexylaniline, 9) resulting from the addition of aniline to 2-hexene (the isomerisation product of 1-hexene), was also obtained along with the expected Markovnikov isomer ( $\mathrm{N}-2$ hexylaniline, 8). The ratio of the isomers $\mathbf{8}$ and $\mathbf{9}$ is approximately 50:50 (Scheme $\left.{ }^{\wedge \wedge} 6\right)$.. This outcome is obviously a consequence of the recognised nature of many rhodium-based catalytic precursors as being good catalysts for olefin isomerisation. This was certainly not observed during the above-described hydroamination of 1-butene because the 2-butene isomer yields the same Markovnikov addition product as 1-butene.

Compared to our results with the $\mathrm{PtBr}_{2} / n \mathrm{Bu}_{4} \mathrm{PBr}$ system (a non-olefin isomerisation catalyst), the rhodium(III)-based catalyst induces a higher M/AM regioselectivity with no other side products (quinoline) except the Markovnikov addition product; nevertheless it readily promotes olefin isomerisation and subsequent hydroamination at the 3-position.

\section{Hydroamination of ethylene by aniline in the presence of $\mathrm{Rh}^{\mathrm{I}}$ precursors}

Finally, we decided to explore the hydroamination of ethylene by aniline in the presence of $\mathrm{Rh}^{\mathrm{I}}$ precursors $\left(\mathrm{Table}^{\wedge \wedge} 10\right)$. This is an idea based on the hypothesis that the active species in the catalytic cycle of the rhodium-catalysed hydroamination are $\mathrm{Rh}^{\mathrm{I}}$

species. ${ }^{\left[15, \wedge 17 a,{ }^{\wedge} 18\right]}$ In view of the extremely important role played by phosphorus ligands in this reaction, especially aromatic phosphines such as $\mathrm{PPh}_{3}$, we were prompted to test the catalytic performance of both Wilkinson's catalysts: $\left[\mathrm{RhCl}\left(\mathrm{PPh}_{3}\right)_{3}\right]$ and the corresponding dimer $\left[\left\{\mathrm{RhCl}\left(\mathrm{PPh}_{3}\right)_{2}\right\}_{2}\right]$, which were directly synthesised from $\mathrm{RhCl}_{3} \cdot 3 \mathrm{H}_{2} \mathrm{O}$ and $\mathrm{PPh}_{3}$ precursors used in this study. ${ }^{[34]}$

Wilkinson and co-workers studied a series of relevant chemical processes involving the $\mathrm{Rh}^{\mathrm{I}}$ complexes, which could be partially applied to the hydroamination mechanism, or at 
least, to provide an insight on relative equilibria. ${ }^{[34]} \mathrm{In}$ fact, $\left[\mathrm{RhCl}\left(\mathrm{PPh}_{3}\right)_{2}\right]$, which is formed from $\mathrm{Rh}^{\mathrm{I}}$ species reacts quickly with ethylene and slower with higher olefins. Furthermore, the formation of the olefin complex is favoured, as in our case, by the presence of $\mathrm{I}^{<\mathrm{M}->}$ rather than $\mathrm{Br}^{<\mathrm{M}->}$ or $\mathrm{Cl}^{<\mathrm{M}->}$ as a consequence of the trans $^{\wedge \wedge}$ effect of $\mathrm{X}^{<\mathrm{M}->}$ when in the position trans to ethylene. ${ }^{[34]}$

As expected, Wilkinson's catalyst allows very high catalytic activities when performing the hydroamination of ethylene by aniline under optimised experimental conditions, using $n \mathrm{Bu}_{4} \mathrm{PI}$ and $\mathrm{I}_{2}$ promoters. Under similar conditions the $\mathrm{RhCl}_{3} \cdot 3 \mathrm{H}_{2} \mathrm{O} / n \mathrm{Bu}_{4} \mathrm{PI} / \mathrm{PPh}_{3} / \mathrm{I}_{2}$ catalytic system afforded slightly higher TON $\left(\mathrm{TON}_{\mathbf{1}}=28\right.$, $\mathrm{TON}_{2}=225, \mathrm{TON}_{3}=3, \mathrm{CE}=484$ ) mainly because it seems to better promote the formation of 2 from $\mathbf{1}$, and thus the hydroamination by more basic amines.

In the same way, Wilkinson's dimer appeared to be a good hydroamination catalyst although the selectivity of the reaction is different because less $\mathrm{N}, \mathrm{N}$-diethylaniline is formed either because the formation of $\mathbf{2}$ is less favoured than in the case of the corresponding monomer, or simply because the reaction is slower. It is important to note that no quinoline was observed when using either of the Wilkinson's complexes.

Our study on the performance of rhodium(I)-phosphine precursors, in the presence of phosphonium salts, could provide important access to a new and large family of asymmetric catalytic systems for the enantioselective intermolecular hydroamination of non-activated olefins by simple amines.

\section{Conclusion}

In summary, the association of $\mathrm{RhCl}_{3} \cdot 3 \mathrm{H}_{2} \mathrm{O} / 2 \mathrm{PPh}_{3} / n \mathrm{Bu}_{4} \mathrm{PI} / \mathrm{I}_{2}$ has been shown to afford excellent catalytic activities for the hydroamination of ethylene and higher non-activated $\alpha$ olefins with aniline. Even more important is to note the very high regioselectivity of this rhodium-based catalytic system towards Markovnikov addition products (up to $100^{\wedge} \%$ for the reaction of 1-hexene with aniline). It is also an excellent catalytic system for the addition of more basic anilines, such as $N$-ethylaniline, to non-activated olefins. 
From a practical point of view, this system offers several advantages because it involves simple starting materials and tolerates the presence of common aromatic phosphines as potential chiral vectors for the enantioselective version of this reaction. Furthermore, good to excellent activities were achieved by "one-pot" addition of $\mathrm{PPh}_{3}$ and $\mathrm{I}_{2}$, a source of an "insitu" generated halide promoter, in the absence of $n \mathrm{Bu}_{4} \mathrm{PI}$.

Research is now in progress to elucidate the nature and the energy of the intermediates of the catalytic cycle of this reaction and to take advantage of these promoting effects to explore the enantioselective intermolecular hydroamination of non-activated alkenes by simple amines in the presence of racemic and chiral $\mathrm{Rh}^{\mathrm{I}}$-based $\mathrm{N}$-heterocyclic carbene-phosphine precursors.

\section{Experimental Section}

\section{Instrumentation}

The GC analyses were performed on a Hewlett--Packard HP^^4890 (FID) chromatograph (HP^^3395 integrator) equipped with a $30^{\wedge \wedge} \mathrm{m}$ HP1 capillary column. The GC-MS analyses were performed on a Hewlett--Packard $\mathrm{HP}^{\wedge \wedge} 6890$ apparatus equipped with a HP^^5973 M ion detector. The NMR analyses were performed on Bruker $\mathrm{AM}^{\wedge \wedge} 250$ machine. Catalytic experiments were conducted in a $100^{\wedge \wedge} \mathrm{mL}$ stainless-steel thermoregulated (electric oven) autoclave with a glass liner and a magnetic stirring bar.

\section{Methods and Materials}

Tetra- $n$-butylphosphonium iodide was prepared from $n \mathrm{Bu}_{3} \mathrm{P}$ and $n \mathrm{BuI}$ (see below), stored under argon, in a freezer, and protected from light. Tetra- $n$-butylphosphonium bromide (Aldrich, $98^{\wedge} \%$ ), tetraphenylphosphonium iodide (Alfa Aesar, $>98^{\wedge} \%$ ), tetra- $n$-butylamonium iodide (Fluka,>99^\%), 1-iodobutane (Alfa Aesar, 99^\%), tri- $n$-butylphosphine (Acros Organics, 95^\%), triphenylphosphine (Aldrich, 99^\%), triphenylphosphite (Acros, 99^\%), trimethylphosphite (Strem, 97^\%), methyldiphenylphosphinite (Acros, 99^\%), tri(4-methoxyphenyl)phosphine (Alfa Aesar, 98^\%), tri((4-trifluoromethyl)phenyl)phosphine (Avocado, 98^\%), tri( $p$-tolyl)phosphine (Fluka,>97^\%), rac-2,2'-bis(diphenylphosphino)-1,1'-binaphthyl (Aldrich, 97^\%), 1,2bis(diphenylphosphino)ethane (Strem, 99^\%), and rhodium trichloride trihydrate (Johnson Matthey, 
$41.92^{\wedge} \%$ ) were used as received. Molecular iodine was purchased from Acros. Aniline (Acros Organics, 99^\% for analysis ACS), $N$-ethylaniline (Acros Organics, 98^\%), morpholine (Fluka, 99^\%), piperidine (Acros Organics, 99^\%), benzylamine (Aldrich,>99.5^\%), $N, N$-di- $n$-butylaniline (Aldrich, 97^\%), 4- $n$-octylaniline (TCI,>95^\%), 1-hexene (Aldrich, 97^\%) and triethylphosphite (Aldrich, 98^\%) were distilled before use and stored under argon. Ethylene (N25) and 1-butene were purchased from Air Liquide. Tricyclohexylphosphine was recrystallised from toluene/methanol. $\left[\mathrm{RhCl}\left(\mathrm{PPh}_{3}\right)_{3}\right],\left[\left\{\mathrm{RhCl}\left(\mathrm{PPh}_{3}\right)_{2}\right\}_{2}\right]$ were prepared according to established methods. ${ }^{[34]}$

\section{Preparation of tetra- $n$-butylphosphonium iodide}

Tri- $n$-butylphosphine $\left(38^{\wedge \wedge} \mathrm{mL}, 0.15 \mathrm{~mol}\right)$ was slowly added to 1 -iodobutane $\left(40^{\wedge \wedge} \mathrm{mL}, 0.35\right.$ mol) under argon. The mixture was stirred for $1^{\wedge \wedge} \mathrm{h}$ at RT and then at $100^{\wedge} \mathrm{C}$ for $20^{\wedge \wedge} \mathrm{h}$. The solution was heated with a heat gun for approximately $15^{\wedge \wedge} \min$. After cooling, the resulting precipitate was washed with diethyl ether $\left(4 \times 50^{\wedge \wedge} \mathrm{mL}\right)$ until a white solid was obtained. Evaporation of residual solvent was carried out under vacuum overnight to afford pure $n \mathrm{Bu}_{4} \mathrm{PI}$ as a white powder $\left(96^{\wedge} \%\right.$ yield). m.p. 95--96^^ $\mathrm{C}^{1}{ }^{1} \mathrm{H}^{\wedge \wedge} \mathrm{NMR}\left(250^{\wedge \wedge} \mathrm{MHz},\left[\mathrm{D}_{6}\right]\right.$ acetone): $\delta=0.96\left(\mathrm{t}, 3^{\wedge} \mathrm{H}, J=3^{\wedge \wedge} \mathrm{Hz}\right), 1.55(\mathrm{~m}$, $\left.2^{\wedge} \mathrm{H}\right), 1.70\left(\mathrm{~m}, 2^{\wedge} \mathrm{H}\right), 2.54^{\wedge} \wedge \mathrm{ppm}\left(\mathrm{m}, 2^{\wedge} \mathrm{H}\right) ;{ }^{31} \mathrm{P}^{\wedge} \wedge \mathrm{NMR}\left(250^{\wedge} \mathrm{MHz},\left[\mathrm{D}_{6}\right]\right.$ acetone $): \delta=33.52^{\wedge \wedge} \mathrm{ppm}(\mathrm{s})$; elemental analysis calcd (\%) for $\mathrm{C}_{16} \mathrm{H}_{36} \mathrm{IP}$ : $\mathrm{C}^{\wedge \wedge} 49.74, \mathrm{H}^{\wedge \wedge 9.39}$; found: $\mathrm{C}^{\wedge \wedge} 49.75, \mathrm{H}^{\wedge} 9.57$.

\section{Typical hydroamination reactions}

Hydroamination of ethylene: The autoclave was charged with $\mathrm{RhCl}_{3} \cdot 3 \mathrm{H}_{2} \mathrm{O}\left(34.0^{\wedge \wedge} \mathrm{mg}\right.$, $\left.0.13^{\wedge \wedge} \mathrm{mmol}\right), \mathrm{I}_{2}\left(2^{\wedge \wedge}\right.$ equiv with respect to $\left.\mathrm{Rh}, 66.0^{\wedge \wedge} \mathrm{mg}, 0.26^{\wedge \wedge} \mathrm{mmol}\right), \mathrm{PPh}_{3}\left(2^{\wedge \wedge}\right.$ equiv with respect to $\left.\mathrm{Rh}, 68.0^{\wedge \wedge} \mathrm{mg}, 0.26^{\wedge \wedge} \mathrm{mmol}\right)$, and $n \mathrm{Bu}_{4} \mathrm{PI}\left(3.3^{\wedge \wedge} \mathrm{g}, 8.45^{\wedge \wedge} \mathrm{mmol}\right)$. The autoclave was closed and submitted to several argon-vacuum cycles. Distilled and degassed aniline $\left(4.1^{\wedge \wedge} \mathrm{mL}, 45^{\wedge \wedge} \mathrm{mmol}\right)$ was then syringed into the autoclave. The ethylene pipe was connected to the autoclave, purged, and the ethylene pressure was adjusted to $25^{\wedge}$ bar at $\mathrm{RT}\left(\mathrm{ca} \cdot \cdot^{\wedge} 100^{\wedge \wedge} \mathrm{mmol}\right)$. The temperature was then raised to $150^{\wedge} \mathrm{C}$. After $96^{\wedge \wedge} \mathrm{h}$, the autoclave was cooled to RT and slowly vented in a fume cupboard. The reaction mixture was poured into diethyl ether $\left(120^{\wedge \wedge} \mathrm{mL}\right)$, stirred for $2^{\wedge \wedge} \mathrm{h}$, and then filtered. The external standard $\left(N, N\right.$-di- $n$-butylaniline, ca. $\left.^{\wedge \wedge} 0.15^{\wedge \wedge} \mathrm{g}\right)$ was added to the collected ethereal phases and the solution was analysed by GC and GCMS. 
$<+>$ Hydroamination of 1-butene: The autoclave was charged with $\mathrm{RhCl}_{3} \cdot 3 \mathrm{H}_{2} \mathrm{O}\left(34.0^{\wedge \wedge} \mathrm{mg}\right.$, $\left.0.13^{\wedge \wedge} \mathrm{mmol}\right), \mathrm{I}_{2}\left(2^{\wedge \wedge}\right.$ equiv with respect to $\left.\mathrm{Rh}, 66.0^{\wedge \wedge} \mathrm{mg}, 0.26^{\wedge \wedge} \mathrm{mmol}\right), \mathrm{PPh}_{3}\left(2^{\wedge \wedge}\right.$ equiv with respect to $\left.\mathrm{Rh}, 68.0^{\wedge \wedge} \mathrm{mg}, 0.26^{\wedge \wedge} \mathrm{mmol}\right)$ and $n \mathrm{Bu}_{4} \mathrm{PI}\left(3.3^{\wedge \wedge} \mathrm{g}, 8.45^{\wedge \wedge} \mathrm{mmol}\right)$. The autoclave was closed and submitted to several argon-vacuum cycles. Distilled and degassed aniline $\left(4.1^{\wedge \wedge} \mathrm{mL}, 45^{\wedge \wedge} \mathrm{mmol}\right)$ was then syringed into the autoclave. Pre-cooled 1-butene $\left(8.9^{\wedge \wedge} \mathrm{mL}, 100^{\wedge \wedge} \mathrm{mmol}\right)$ was then transferred from a Schlenk flask to the previously cooled (in a liquid nitrogen bath) autoclave by a cannula. The whole system was warmed to RT and then the temperature was raised to $150^{\wedge} \mathrm{C}$. After $96^{\wedge \wedge} \mathrm{h}$, the autoclave was cooled to RT and slowly vented in a fume cupboard. The reaction mixture was poured into diethyl ether $\left(120^{\wedge \wedge} \mathrm{mL}\right)$, stirred for $2^{\wedge \wedge} \mathrm{h}$, and then filtered. The external standard (4-noctylaniline, ca. ${ }^{\wedge} 0.15^{\wedge \wedge} \mathrm{g}$ ) was added to the collected ethereal phases and the solution was analysed by GC and GCMS.

<+>Hydroamination of 1-hexene: The autoclave was charged with $\mathrm{RhCl}_{3} \cdot 3 \mathrm{H}_{2} \mathrm{O}\left(34.0^{\wedge \wedge} \mathrm{mg}\right.$, $\left.0.13^{\wedge \wedge} \mathrm{mmol}\right), \mathrm{I}_{2}\left(2^{\wedge \wedge}\right.$ equiv with respect to $\left.\mathrm{Rh}, 66.0^{\wedge \wedge} \mathrm{mg}, 0.26^{\wedge \wedge} \mathrm{mmol}\right), \mathrm{PPh}_{3}\left(2^{\wedge \wedge}\right.$ equiv with respect to $\left.\mathrm{Rh}, 68.0^{\wedge \wedge} \mathrm{mg}, 0.26^{\wedge \wedge} \mathrm{mmol}\right)$ and $n \mathrm{Bu}_{4} \mathrm{PI}\left(3.3^{\wedge \wedge} \mathrm{g}, 8.45^{\wedge \wedge} \mathrm{mmol}\right)$. The autoclave was closed and submitted to several argon-vacuum cycles. Distilled and degassed aniline $\left(4.1^{\wedge \wedge} \mathrm{mL}, 45^{\wedge \wedge} \mathrm{mmol}\right)$ and 1-hexene $\left(11.3^{\wedge \wedge} \mathrm{mL}, 91^{\wedge \wedge} \mathrm{mmol}\right)$ were then sequentially syringed into the autoclave. The temperature was then raised to $150^{\wedge}{ }^{\circ} \mathrm{C}$. After $96^{\wedge \wedge} \mathrm{h}$, the autoclave was cooled to RT and slowly vented in a fume cupboard. The reaction mixture was then poured into diethyl ether $\left(120^{\wedge \wedge} \mathrm{mL}\right)$, and stirred for $2^{\wedge \wedge} \mathrm{h}$, then filtered. The external standard $\left(N, N\right.$-di- $n$-butylaniline, $\left.c a \cdot \cdot^{\wedge} 0.15^{\wedge \wedge} \mathrm{g}\right)$ was added to the collected ethereal phases and the solution was analysed by GC and GCMS.

$<+>$ Taking into account the liquid nature of both substrates (aniline and 1-hexene), the hydroamination of 1-hexene by aniline could analogously be carried out using Schlenk glassware techniques.

\section{Acknowledgements}

The $\langle$ cgs $>$ Centre National de la Recherche Scientifique (France) $\langle/$ cgs $\rangle$, the $\langle$ cgs $\rangle$ FSE (Fond Social European) $\langle/$ cgs $\rangle$, and the $\langle$ cgs $>A N R</ c g s\rangle(\langle\operatorname{cgs}>$ Agence National de la Recherche Scientifique $\langle/$ cgs $\rangle,\left\langle c g n>N T 09 \_442499</\right.$ cgn $>$ ) are acknowledged for financial support. We gratefully acknowledge Dr. J.-J. Bonnet and Dr. D. Neibecker for academic support and Dr. F. Malbosc (Solvionic) for helpful discussions. 
$<$ lit1 $><$ book $>$ A. ${ }^{\wedge}$ E. Schweizer, R..$^{\wedge}$ L. Fowlkes, J.^^${ }^{\wedge}$ H. Mc ${ }^{\wedge \wedge}$ Clain, T. ${ }^{\wedge}$ E. Whyte, ${ }^{\wedge \wedge} \mathrm{Jr}$. in Kirk-Othmer Encyclopedia of Chemistry and Technology, Vol.^^2, Wiley, New York, 1978, pp. ${ }^{\wedge \wedge} 272--283</$ book $>$.

$\langle$ lit2 $><$ lit_a $>\langle$ book $>H . \wedge \wedge$ B. Bathina, R.^^A. Reck in Kirk-Othmer Concise Encyclopedia of Chemistry and Technology, Wiley, New York, 1985, p.^^83</book>; <lit_b $><$ book $>$ K. Weissermel, H.-J. Harpe, Industrial Organic Chemistry, 2nd ed., Wiley-VCH, Weinheim, 1993</book>.

$<$ lit3><book>J. March, Advanced Organic Chemistry, 4th ed., Wiley, New York, $1992</$ book $>$.

$<$ lit4><jnl>P. Sabatier, A. Mailhe, Compt. Rend. Sc. Heb. Acad. Sci. 1909, 148, 898</jnl>. <lit5><jnl>A. Baiker, J. Kijenski, Catal. Rev. Sci. Eng. 1985, 27, 653--697</jnl>. $<$ lit6><book>P.^^D. Sherman, ${ }^{\wedge \wedge} \mathrm{Jr}, \mathrm{P} .{ }^{\wedge} \wedge$ R. Kavasmaneck in Kirk-Othmer Encyclopedia of Chemistry and Technology, Vol.^^2, Wiley, New York, 1980, p. ${ }^{\wedge} 338</$ book>. $<$ lit7><book>J. Falbe, New Syntheses with Carbon Monoxide, Springer Verlag, Berlin, $1980</$ book $>$.

$<$ lit8 $><$ lit_a $><$ jnl $>$ D. Steinborn, R. Taube, Z. Chem. 1986, 349--359</jnl $>$; $<$ lit_b $><$ book $>$ R. Taube in Applied Homogeneous Catalysis with Organometallic Complexes, Vol.^^2 (Eds.: B. Cornils, W. Herrmann), Wiley-VCH, Weinheim, 1996, pp.^^507-$521</$ book $>$.

$<$ lit9>For selected reviews, see: <lit_a $><j n l>M .^{\wedge}{ }^{\wedge}$ B. Gasc, A. Lattes, J.-J. Perié, Tetrahedron 1983, 39, 703--731</jnl>; <lit_b ><jnl>JJ-J. Brunet, D. Neibecker, F. Niedercorn, J. Mol. Catal. 1989, 49, 235--259</jnl>; <lit_c ><jnl>T.^^E. Müller, M. Beller, Chem. Rev. 1998, 98, 675--703</jnl>; <lit_d ><book>T.^^E. Müller, M. Beller in Transition Metals for Organic Synthesis Vol.^^2 (Eds.: M. Beller, C. Bolm), Wiley-VCH, Weinheim, 1998, pp. ${ }^{\wedge} 316--330</$ book>; $<$ lit_e $><$ book>J-J. Brunet, D. Neibecker in Catalytic Heterofunctionalization (Eds.: A. Togni, H. Grützmacher), Wiley-VCH, Weinheim, 2001, pp. ${ }^{\wedge} 91--141</$ book>; <lit_f $><$ jnl $>$ J. Seayad, A. Tillack, C.^^G. Hartung, M. Beller, Adv. Synth. Catal. 2002, 344, 795--813</jnl〉; <lit_g ><jnl>M. Beller, C. 
Breindl, M. Eichberger, C-G. Hartung, J. Seayad, O.-R. Thiel, A. Tillack, H. Trauthwein, Synlett 2002, 1579--1594</jnl >; <lit_h $><$ jnl $>$ F. Pohlki, S. Doye, Chem. Soc. Rev. 2003, 32, 104--114</jnl >; <lit_i ><jnl >I. Bytschkov, S. Doye, Eur. J. Org. Chem. 2003, 935--946</jnl >; <lit_j ><jnl >M. Beller, J. Seyad, A. Tillack, H. Jiao, Angew. Chem. 2004, 116, 3448--3479; Angew. Chem. Int. Ed. 2004, 43, 3368-3398</jnl>; <lit_k><jnl>F. Alonso, P. Beletskaya Irina, M. Yus, Chem. Rev. 2004, 104, 3079--3160</jnl >; <lit_l><jnl>K.^^C. Hultzsch, Adv. Synth. Catal. 2005, 347, 367-391</jnl>; <lit_m><jnl>R.^^A. Widenhoefer, X. Han, Eur. J. Org. Chem. 2006, 4555-4563</jnl>; <lit_n><jnl>R. Severin, S. Doye, Chem. Soc. Rev. 2007, 36, 1407-$1420</$ jnl $>$; <lit_o $><$ jnl $>$ T. ${ }^{\wedge}{ }^{\wedge}$ E. Müller, K.^^C. Hultzsch, M. Yus, F. Foubelo, M. Tada, Chem. Rev. 2008, 108, 3795--3892</jnl>; <lit_p ><jnl>S. Doye, Sci. Synth. 2009, 40a, 241--304</jnl>; <lit_q ><jnl >K.^^D. Hesp, M. Stradiotto, ChemCatChem 2010, 2, 1192--1207</jnl>; for selected reports on intramolecular hydroamination, see: <lit_r ><jnl>S. Hong, T.^^J. Marks, Acc. Chem. Res. 2004, 37, 673--686</jnl>; $\left\langle\right.$ lit_s $>\left\langle\right.$ jnl $>$ L. ${ }^{\wedge}$ D. Field, B. ${ }^{\wedge}$ A. Messerle, K. ${ }^{\wedge}$ Q. Vuong, P. Turner, Organometallics 2005, 24, 4241--4250</jnl $>$; <lit_t $><$ jnl $>$ J. Zhao, T.^^J. Marks, Organometallics 2006, 25, 4763--4772</jnl>; <lit_u><jnl>D.^^V. Gribkov, K. ${ }^{\wedge \wedge}$ C. Hultzsch, F. Hampel, J. Am. Chem. Soc. 2006, 128, 3748--3759</jnl>, and references therein; $<$ lit_v $><$ jnl $>H .{ }^{\wedge}$ F. Yuen, T.^^J. Marks, Organometallics 2009, 28, 2423--2440</jnl>; $<$ lit_w $><$ jnl $>$ J. Jenter, A. Luehl, P.^^W. Roesky, S. Blechert, J. Organomet. Chem. 2011, 696, 406--418</jnl >; <lit_x $><$ jnl $>S .{ }^{\wedge} \wedge$ R. Beeren, S.^^L. Dabb, G. Edwards, M. ${ }^{\wedge}$ K. Smith, A. ${ }^{\wedge}$ C. Willis, B. ${ }^{\wedge \wedge}$ A. Messerle, New J. Chem. 2010, 34, 1200--

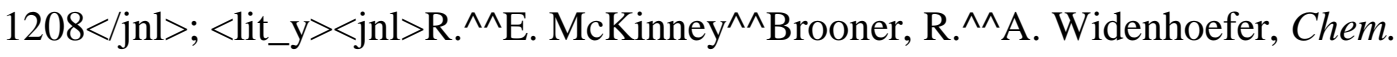
Eur. J. 2011, 17, 6170--6178</jnl >; <lit_z ><jnl >J. Deschamp, J. Collin, J. Hannedouche, E. Schulz, Eur. J. Org. Chem. 2011, 2011, 3329--3338</jnl>; $<$ lit_aa $><$ jnl $>$ Z. Liu, H. Yamamichi, S.^^T. Madrahimov, J.^^F. Hartwig, J. Am. Chem. Soc. 2011, 133, 2772--2782</jnl>; for selected reports on hydroamination of alkynes and/or activated substrates, see: $\left\langle\right.$ lit_ab $>\left\langle\right.$ jnl $>\mathrm{J} .{ }^{\wedge} \mathrm{J}$. Brunet, N.^^C. Chu, O. Diallo, E. Mothes, J. Mol. Catal. A 2003, 198, 107--110</jnl>; <lit_ac ><jnl>L. Fadini, A. Togni, Chem. Commun. 2003, 30--31</jnl $>$; <lit_ad $><$ jnl $>$ J.^^J. Brunet, N.^^C. Chu, O. 
Diallo, S. Vincendeau, J. Mol. Catal. A 2005, 240, 245--248</jnl >; <lit_ae $><$ jnl $>$ D. Karshtedt, T.^^A. Bell, T.^^D. Tilley, J. Am. Chem. Soc. 2005, 127, 12640-12646</jnl >; <lit_af ><jnl >L. ${ }^{\wedge}$ L. Anderson, J. Arnold, R.^^G. Bergman, J. Am. Chem. Soc. 2005, 127, 14542--14543</jnl >; <lit_ag ><jnl>A.^^M. Johns, M. Utsunomiya, C. ${ }^{\wedge}$ D. Incarvito, J.^^F. Hartwig, J. Am. Chem. Soc. 2006, 128, 1828--1839</jnl>, and references therein; <lit_ah $><j n l>K$ K. Komeyama, T. Morimoto, K. Takaki, Angew. Chem. 2006, 118, 3004--3007; Angew. Chem. Int. Ed. 2006, 45, 2938--2941</jnl>; $<$ lit_ai $><$ jnl $>$ J.^^G. Taylor, N. Whittall, K. ${ }^{\wedge}$ K. Hii, Org. Lett. 2006, 8, 3561-3564</jnl>; <lit_aj><jnl>C. Brouwer, C. He, Angew. Chem. 2006, 118, 1776--1779; Angew. Chem. Int. Ed. 2006, 45, 1744--1747</jnl>; <lit_ak><jnl >L. Fadini, A. Togni, Helvetica Chimica Acta 2007, 90, 411--424</jnl>; <lit_al $><$ jnl $>$ J. Zhou, J.^^${ }^{\wedge}$. Hartwig, J. Am. Chem. Soc. 2008, 130, 12220--12221</jnl >; <lit_am $><$ jnl $>$ J.^^L. McBee, A. ${ }^{\wedge}$ T. Bell, T. ${ }^{\wedge}$ D. Tilley, J. Am. Chem. Soc. 2008, 130, 16562--16571</jnl>; $<$ lit_an $><$ jnl $>$ J. Cho, T. ${ }^{\wedge}$ K. Hollis, T. ${ }^{\wedge}$ R. Helgert, E. ${ }^{\wedge}$ J. Valente, Chem. Commun. 2008, 5001--5003</jnl>; <lit_ao><jnl>X. Giner, C. Nájera, Org. Lett. 2008, 10, 2919-2922</jnl>; <lit_ap ><jnl>L. Fadini, A. Togni, Tetrahedron: Asymmetry 2008, 19, 2555--2562</jnl >; <lit_aq ><jnl >H. Li, S.^^D. Lee, R.^^A. Widenhoefer, J. Organomet. Chem. 2011, 696, 316--320</jnl>; <lit_ar><jnl>M. Biyikal, M. Porta, P.^^W. Roesky,

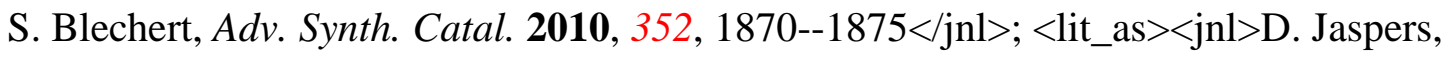
S. Doye, Synlett 2011, 10, 1444--1448</jnl>.

$<$ lit10 $><$ lit_a $><$ jnl $>$ V. Khedkar, A. Tillack, C. Benisch, J-P. Melder, M. Beller, J. Mol. Catal. A 2005, 241, 175--183</jnl>; <lit_b ><jnl>C.^^S. Yi, S.^^Y. Yun, Org. Lett. 2005, 7, $2181--2183<$ jnl $>$.

$<$ lit11 $><$ lit_a $><$ jnl $>$ S. Anguille, J.^^J. Brunet, N.^^C. Chu, O. Diallo, C. Pages, S.

Vincendeau, Organometallics 2006, 25, 2943--2948</jnl >; <lit_b $><$ jnl $>$ J.^^J. Brunet, N. ${ }^{\wedge}$ C. Chu, M. Rodriguez-Zubiri, Eur. J. Inorg. Chem. 2007, 2007, 4711--4722</jnl>; $\langle$ lit_c $><$ jnl $>$ M. Rodriguez-Zubiri, S. Anguille, J.^^J. Brunet, J. Mol. Catal. A 2007, $271,145--151</ j n l>$. 
$<$ lit12><jnl>P.^^A. Dub, M. Rodriguez-Zubiri, C. Baudequin, R. Poli, Green Chem. 2010, $12,1392</ \mathrm{jnl}>$.

$<$ lit13><lit_a $><$ jnl $>$ P.^^A. Dub, M. Rodriguez-Zubiri, J.^^C. Daran, J.^^J. Brunet, R. Poli, Organometallics 2009, 28, 4764--4777</jnl >; <lit_b ><jnl >G. Aullón, K. Gomez, G.

Gonzalez, S. Jansat, M. Martinez, R. Poli, M. Rodriguez-Zubiri, Inorg. Chem. 2011, 50, $5628--5636</$ jnl $>$.

$<$ lit14><jnl>C. Baudequin, J.^^J. Brunet, M. Rodriguez-Zubiri, Organometallics 2007, 26, 5264--5266</jnl >.

$<$ lit15><jnl>D.^^R. Coulson, Tetrahedron Lett. 1971, 12, 429--430</jnl>.

$<$ lit16><pat>D. ${ }^{\wedge}$ R. Coulson (E. ${ }^{\wedge}$ I. du Pont de ${ }^{\wedge \wedge}$ Nemours and Co. $),<$ patn/>US-3758586, $1973</$ pat $>$.

$<$ lit17><lit_a $><$ jnl $>$ S.^^E. Diamond, A. Szalkiewicz, F. Mares, J. Am. Chem. Soc. 1979, 101, 490--49</jnl>; <lit_b ><pat>E. Diamond, F. Mares (Allied Chemical Corp.), $<$ patn/>US-4215218, 1980</pat $>$.

$<$ lit18><jnl >S.^^E. Diamond, A. Szalkiewicz, F. Mares, Fundam. Res. Homogeneous Catal. 1979, 3, 345--358</jnl >.

<lit19><jnl>D. Steinborn, R. Taube, Z. Chem. 1986, 26, 349--359</jnl>.

$<$ lit20><pat>E. Krukowka, R. Taube, D. Steinborn, (Technische Hochschule Leuna)

<patn/>DD-296909, 1991</pat>.

$<$ lit21><jnl>C. Hahn, M. Spiegler, E. Herdtweck, R. Taube, Eur. J. Inorg. Chem. 1999, 435-$440</$ jnl $>$, and references therein.

$<$ lit22><jnl>Z. Zhang, S. Du Lee, R.^^A. Widenhoefer, J. Am. Chem. Soc. 2009, 131, 5372-$5373</$ jnl $>$.

$<$ lit23 $><$ jnl $>$ A. ${ }^{\wedge}$ L. Reznichenko, H. ${ }^{\wedge} N$ N. Nguyen, K.^^C. Hultzsch, Angew. Chem. 2010, 122, 9168--9171; Angew. Chem. Int. Ed. 2010, 49, 8984--8987</jnl>.

$<$ lit24 $><$ jnl $>$ J.^^J. Brunet, M. Cadena, N.^^C. Chu, O. Diallo, K. Jacob, E. Mothes, Organometallics 2004, 23, 1264--1268</jnl >. 
$<$ lit25 $><$ lit_a $><$ jnl $>$ E. Fagadar-Cosma, B. Maranescu, G. Fagadar-Cosma, C. Cozmiuc, Revista de Chimie 2005, 56, 947--950</jnl >; <lit_b $>\langle$ jnl $>$ W.^^I. Cross S.^^M. Godfrey, C. ${ }^{\wedge}$ A. McAuliffe, R.^^G. Pritchard, J.^^M. Sheffield, G. ${ }^{\wedge}$ M. Thompson, $J$. Chem. Soc. Dalton Trans 1999, 2795--2798</jnl>, and references therein; $\left\langle\right.$ lit_c $><$ jnl $>$ N. Bricklebank, S.^^M. Godfrey, A. ${ }^{\wedge}$ G. Mackie, C.^^A. McAuliffe, R.^^G. Pritchard, P.^^J. Kobryn, J. Chem. Soc. Dalton Trans 1993, 101--103</jnl>; $<$ lit_d $><$ jnl $>$ K.^^B. Dillon, J. Lincoln, Polyhedron 1989, 8, 1445--1446</jnl >; <lit_e ><jnl>F.^^A. Cotton, P.^^A. Kibala, J. Am. Chem. Soc. 1987, 109, 3308-3312</jnl >; <lit_f $><$ jnl $>$ A.^^D. Beveridge, G.^^S. Harris, F. Inglis, J. Chem. Soc. A 1966, 520--528</jnl >

$<$ lit26><jnl >J.^^J. Brunet, M. Cadena, N. ${ }^{\wedge}$ C. Chu, O. Diallo, K. Jacob, E. Mothes, Organometallics 2004, 23, 1264--1268</jnl >.

$<$ lit27><lit_a $><$ jnl $>$ G. Pez, J.^^E. Galles, Pure Appl. Chem. 1985, 57, 1917--1926</jnl>;

<lit_b ><pat>G. Pez (Allied Chemical Corp.), <patn/>US-4302603, 1981</pat>. $<$ lit28><lit_a $><$ jnl $>Y$. Li, T.^^J. Marks, Organometallics 1996, 15, 3770--3772</jnl>; <lit_b $><$ jnl $>$ J.^^S. Ryu, G. ${ }^{\wedge} Y$ Y. Li, T.^^J. Marks, J. Am. Chem. Soc. 2003, 125, 12584-$12605</$ jnl $>$.

$<$ lit29><lit_a $><$ jnl $>$ J. Zhang, C.^^G. Yang, C. He, J. Am. Chem. Soc. 2006, 128, 1798-1799</jnl>; <lit_b><jnl>J.^^M. Huang, C.^^M. Wong, F.^^X. Xub, T.^^P. Loh, Tetrahedron Lett. 2007, 48, 3375--3377</jnl>.

$<$ lit30><jnl>P. Yin, T.^^P. Loh, Org. Lett. 2009, 11, 3791--3793</jnl>. $<$ lit31><jnl>J.^^J. Brunet, N.^^C. Chu, O. Diallo, Organometallics 2005, 24, 3104-$3110</ j n l>$.

$<$ lit32 ><jnl>C. Michon, F. Medina, F. Capet, P. Roussel, F. Agbossou-Niedercorn, Adv. Synth. Catal. 2010, 352, 3293--3305</jnl>.

$<$ lit33><jnl>A. Panunzi, A. De^^^enzi, R. Palumbo, G. Paiaro, J. Am. Chem. Soc. 1969, 91, 3879--3883</jnl>. 
$<$ lit34 $><\mathrm{jnl}>\mathrm{J} .{ }^{\wedge}$ A. Osborn, F.^^H. Jardine, J.^^F. Young, G. Wilkinson, J. Chem. Soc. A 1966, 1711--1732</jnl >

Received: January 23, 2012

Published online on $\langle$ ? $><?>$

Scheme ${ }^{\wedge} 1$ Industrial synthesis of amines by hydroformylation/hydrogenation sequence and by hydration. ${ }^{[4--7]}$

Scheme $\mathrm{A}^{\wedge} 2$ Addition of an $\mathrm{N}<\mathrm{C}->\mathrm{H}$ bond across a double bond: hydroamination of olefins. $\mathrm{M}=$ metal.

Scheme $\mathrm{S}^{\wedge 3}$ Reaction of phosphorus (III) derivatives with molecular halides.

Scheme $\mathrm{e}^{\wedge} 4$ Formation of a zwitterionic complex by addition of aniline to ethylene coordinated to a $\mathrm{Pt}^{\mathrm{II}}$ complex and further elimination of the hydroamination product.

Scheme ${ }^{\wedge \wedge} 5$ Products formed in the $\mathrm{RhCl}_{3} \cdot 3 \mathrm{H}_{2} \mathrm{O}$-catalysed hydroamination of 1-butene by aniline.

Scheme ${ }^{\wedge} 6$ Products formed in the $\mathrm{RhCl}_{3} \cdot 3 \mathrm{H}_{2} \mathrm{O}$-catalysed hydroamination of 1-hexene by aniline.

Table ${ }^{\wedge} 1<\mathrm{w}=1>$ Effect of the amount of $\mathrm{PPh}_{3}$ on the $\mathrm{RhCl}_{3} \cdot 3 \mathrm{H}_{2} \mathrm{O}$-catalysed hydroamination of ethylene by aniline. ${ }^{\text {[a] }}$

\begin{tabular}{|l|l|l|l|l|l|l|}
\hline Entry & $\mathrm{PPh}_{3}{ }^{\wedge}[$ equiv] & $\mathrm{I}_{2}^{\wedge \wedge}[$ equiv] & $\mathrm{TON} \mathrm{1}^{[\mathrm{b}]}$ & $\mathrm{TON} \mathrm{2}^{[\mathrm{b}]}$ & $\mathrm{TON} \mathrm{3}^{[\mathrm{b}]}$ & $\mathrm{CE}^{[\mathrm{c}]}$ \\
\hline 1 & 1 & 2 & $49<\mathrm{dp}>$ & $192<\mathrm{dp}>$ & 5 & $442<\mathrm{dp}>$ \\
\hline 2 & 2 & 2 & $21<\mathrm{dp}>$ & $230<\mathrm{dp}>$ & 3 & $487<\mathrm{dp}>$ \\
\hline 3 & 2 & -- & $114<\mathrm{dp}>$ & $114<\mathrm{dp}>$ & 7 & $355<\mathrm{dp}>$ \\
\hline 4 & 3 & -- & $148<\mathrm{dp}>$ & $101<\mathrm{dp}>$ & 3 & $356<\mathrm{dp}>$ \\
\hline 5 & 5 & -- & $129<\mathrm{dp}>$ & $40<\mathrm{dp}>$ & 2 & $213<\mathrm{dp}>$ \\
\hline
\end{tabular}



10 $31<\mathrm{dp}>$ $1<\mathrm{dp}>$ $36<\mathrm{dp}>$

[a] $]^{\wedge \wedge}$ Reaction conditions: $\mathrm{RhCl}_{3} \cdot 3 \mathrm{H}_{2} \mathrm{O}\left(34.2^{\wedge \wedge} \mathrm{mg}, 0.13^{\wedge \wedge} \mathrm{mmol}\right), \mathrm{PPh}_{3}, n \mathrm{Bu}_{4} \mathrm{PI}\left(3.3^{\wedge \wedge} \mathrm{g}\right.$, 8.45^^ $\mathrm{mmol}, 65^{\wedge \wedge}$ equiv), $\mathrm{I}_{2}\left(0.066^{\wedge \wedge} \mathrm{g}, 0.26^{\wedge \wedge} \mathrm{mmol}, 2^{\wedge \wedge}\right.$ equiv $), \mathrm{PhNH}_{2}\left(4.1^{\wedge \wedge} \mathrm{mL}\right.$, 45.5^^ $\mathrm{mmol}, 350^{\wedge \wedge}$ equiv $), \mathrm{C}_{2} \mathrm{H}_{4}\left(25^{\wedge \wedge}\right.$ bar, ca. ${ }^{\wedge \wedge} 100^{\wedge \wedge} \mathrm{mmol}, 770^{\wedge \wedge}$ equiv $), 150^{\wedge}{ }^{\circ} \mathrm{C}, 96^{\wedge \wedge} \mathrm{h}$. $[\mathrm{b}]^{\wedge \wedge} N$-ethylaniline (1), $N, N$-diethylaniline (2), 2-methyl-quinoline (3). [c] $]^{\wedge \wedge} \mathrm{TON}_{1}+2 \mathrm{TON}_{2}$ $+2 \mathrm{TON}_{3}$.

Table ${ }^{\wedge} 2<\quad<w=1>$ Effect of the nature of the phosphorus ligand on the $\mathrm{RhCl}_{3} \cdot 3 \mathrm{H}_{2} \mathrm{O}$ catalysed hydroamination of ethylene by aniline in the presence of $\mathrm{I}_{2}{ }^{[\mathrm{a}]}$

\begin{tabular}{|c|c|c|c|c|c|c|}
\hline Entry & Ligand $^{\wedge \wedge}$ [equiv] & $t^{\wedge \wedge}[\mathrm{h}]$ & TON $\mathbf{1}^{[b]}$ & TON $2^{[b]}$ & TON $3^{[b]}$ & $\mathrm{CE}^{[\mathrm{c}]}$ \\
\hline 1 & $\mathrm{P}(\mathrm{OPh})_{3}(1)$ & 24 & $13<\mathrm{dp}>$ & $1<\mathrm{dp}>$ & $7<\mathrm{dp}>$ & $29<d p>$ \\
\hline 2 & $\mathrm{P}(\mathrm{OPh})_{3}(2)$ & 24 & $19<\mathrm{dp}>$ & $--<\mathrm{dp}>$ & $3<\mathrm{dp}>$ & $25<\mathrm{dp}>$ \\
\hline 3 & $\mathrm{P}(\mathrm{OMe})_{3}(1)$ & 24 & $11<\mathrm{dp}>$ & $2<\mathrm{dp}>$ & $8<\mathrm{dp}>$ & $31<\mathrm{dp}>$ \\
\hline 4 & $\mathrm{P}(\mathrm{OMe})_{3}(2)$ & 24 & $11<\mathrm{dp}>$ & $2<\mathrm{dp}>$ & $11<\mathrm{dp}>$ & $37<\mathrm{dp}>$ \\
\hline 5 & $\mathrm{P}(\mathrm{OMe})_{3}(2)$ & 96 & $12<\mathrm{dp}>$ & $3<\mathrm{dp}>$ & $7<\mathrm{dp}>$ & $32<\mathrm{dp}>$ \\
\hline 6 & $\mathrm{P}(\mathrm{OEt})_{3}(1)$ & 24 & $12<\mathrm{dp}>$ & $--\langle d p>$ & $9<\mathrm{dp}>$ & $30<\mathrm{dp}>$ \\
\hline 7 & $\mathrm{P}(\mathrm{OEt})_{3}(2)$ & 24 & $13<\mathrm{dp}>$ & $--\langle d p>$ & $10<\mathrm{dp}>$ & $33<\mathrm{dp}>$ \\
\hline 8 & $n \mathrm{Bu}_{3} \mathrm{P}(1)$ & 24 & $10<\mathrm{dp}>$ & $2<\mathrm{dp}>$ & $9<\mathrm{dp}>$ & $32<\mathrm{dp}>$ \\
\hline 9 & $n \mathrm{Bu}_{3} \mathrm{P}(2)$ & 24 & $9<\mathrm{dp}>$ & $1<\mathrm{dp}>$ & $8<\mathrm{dp}>$ & $27<\mathrm{dp}>$ \\
\hline 10 & $n \mathrm{Bu}_{3} \mathrm{P}(2)$ & 96 & $14<\mathrm{dp}>$ & $5<\mathrm{dp}>$ & $11<\mathrm{dp}>$ & $46<\mathrm{dp}>$ \\
\hline 11 & $\mathrm{PCy}_{3}(2)$ & 96 & $26<\mathrm{dp}>$ & $0<\mathrm{dp}>$ & $12<\mathrm{dp}>$ & $50<\mathrm{dp}>[\mathrm{d}]$ \\
\hline 12 & $\mathrm{P}(\mathrm{OMe}) \mathrm{Ph}_{2}(2)$ & 96 & $104<d p>$ & $13<\mathrm{dp}>$ & $8<\mathrm{dp}>$ & $147<\mathrm{dp}>$ \\
\hline
\end{tabular}




\begin{tabular}{|l|l|l|l|l|l|l|}
\hline 13 & dppe (1) & 24 & $106<\mathrm{dp}>$ & $16<\mathrm{dp}>$ & $8<\mathrm{dp}>$ & $154<\mathrm{dp}>$ \\
\hline 14 & binap (1) & 24 & $119<\mathrm{dp}>$ & $50<\mathrm{dp}>$ & $4<\mathrm{dp}>$ & $227<\mathrm{dp}>$ \\
\hline 15 & binap (1) & 96 & $53<\mathrm{dp}>$ & $203<\mathrm{dp}>$ & $--<\mathrm{dp}>$ & $459<\mathrm{dp}>$ \\
\hline 16 & $\mathrm{P}\left(p-\mathrm{CF}_{3} \mathrm{C}_{6} \mathrm{H}_{4}\right)_{3}(2)$ & 96 & $46<\mathrm{dp}>$ & $4<\mathrm{dp}>$ & $--<\mathrm{dp}>$ & $54<\mathrm{dp}>$ \\
\hline 17 & $\mathrm{P}\left(p-\mathrm{CH}_{3} \mathrm{C}_{6} \mathrm{H}_{4}\right)_{3}(2)$ & 96 & $22<\mathrm{dp}>$ & $250<\mathrm{dp}>$ & $3<\mathrm{dp}>$ & $528<\mathrm{dp}>$ \\
\hline 18 & $\mathrm{P}\left(p-\mathrm{OCH}_{3} \mathrm{C}_{6} \mathrm{H}_{4}\right)_{3}$ & 96 & $143<\mathrm{dp}>$ & $64<\mathrm{dp}>$ & $--<\mathrm{dp}>$ & $271<\mathrm{dp}>$ \\
\hline
\end{tabular}

[a] $]^{\wedge \wedge}$ Reaction conditions: $\mathrm{RhCl}_{3} \cdot 3 \mathrm{H}_{2} \mathrm{O}\left(34.2^{\wedge \wedge} \mathrm{mg}, 0.13^{\wedge \wedge} \mathrm{mmol}\right)$, phosphine ligand, $\mathrm{I}_{2}$ (0.066^^ $\mathrm{g}, 0.26^{\wedge \wedge} \mathrm{mmol}, 2^{\wedge \wedge}$ equiv), $n \mathrm{Bu}_{4} \mathrm{PI}\left(3.3^{\wedge \wedge} \mathrm{g}, 8.45^{\wedge \wedge} \mathrm{mmol}, 65^{\wedge \wedge}\right.$ equiv), $\mathrm{PhNH}_{2}$ (4.1 $1^{\wedge \wedge} \mathrm{mL}, 45.5^{\wedge \wedge} \mathrm{mmol}, 350^{\wedge \wedge}$ equiv), $\mathrm{C}_{2} \mathrm{H}_{4}\left(25^{\wedge \wedge}\right.$ bar, ca. $100^{\wedge \wedge} \mathrm{mmol}, 770^{\wedge \wedge}$ equiv $), 150^{\wedge}{ }^{\circ} \mathrm{C}$. $[\mathrm{b}]^{\wedge \wedge} N$-ethylaniline (1), $N, N$-diethylaniline (2), 2-methyl-quinoline (3). [c] $]^{\wedge \wedge} \mathrm{TON}_{1}+2 \mathrm{TON}_{2}$ $+2 \mathrm{TON}_{3} \cdot[\mathrm{d}]^{\wedge \wedge}$ Without $\mathrm{I}_{2} \cdot \mathrm{Cy}=$ cyclohexyl

Table $\wedge^{\wedge} 3<\mathrm{w}=1>$ Effects of the nature of the starting amine on the $\mathrm{RhCl}_{3} \cdot 3 \mathrm{H}_{2} \mathrm{O}$-catalysed hydroamination of ethylene. ${ }^{[a]}$

\begin{tabular}{|l|l|l|l|l|l|l|}
\hline Entry & Amine & $\mathrm{p} K_{\mathrm{b}}$ & $t^{\wedge \wedge}[\mathrm{h}]$ & Product $(\mathrm{s})^{[\mathrm{b}]}$ & $\mathrm{TON}$ & $\mathrm{CE}^{[\mathrm{c}]}$ \\
\hline 1 & aniline & 9.42 & 24 & $\mathbf{1}$ & $84<\mathrm{dp}>$ & $383<\mathrm{dp}>$ \\
\hline 2 & & & & $\mathbf{2}$ & $147<\mathrm{dp}>$ & \\
\hline 3 & N-ethylaniline & 8.88 & 10 & $\mathbf{2}$ & $2<\mathrm{dp}>$ & \\
\hline 4 & N-ethylaniline & 8.88 & 24 & $\mathbf{2}$ & $187<\mathrm{dp}>$ & $187<\mathrm{dp}>$ \\
\hline & benzylamine & 4.67 & 96 & $\mathbf{6}$ & $267<\mathrm{dp}>$ & $267<\mathrm{dp}>$ \\
\hline
\end{tabular}




\begin{tabular}{|l|l|l|l|l|l|c|}
\hline 5 & morpholine & 5.64 & 24 & $\mathbf{4}$ & $4<\mathrm{dp}>$ & $4<\mathrm{dp}>$ \\
\hline 6 & piperidine & 2.89 & 24 & $\mathbf{5}$ & $4<\mathrm{dp}>$ & $4<\mathrm{dp}>$ \\
\hline
\end{tabular}

[a] $]^{\wedge \wedge}$ Reaction conditions: $\mathrm{RhCl}_{3} \cdot 3 \mathrm{H}_{2} \mathrm{O}\left(34.2^{\wedge \wedge} \mathrm{mg}, 0.13^{\wedge \wedge} \mathrm{mmol}, 1^{\wedge \wedge}\right.$ equiv $), \mathrm{PPh}_{3}\left(68.2^{\wedge \wedge} \mathrm{mg}\right.$, $0.26^{\wedge \wedge} \mathrm{mmol}, 2^{\wedge \wedge}$ equiv), $n \mathrm{Bu}_{4} \mathrm{PI}\left(3.3^{\wedge \wedge} \mathrm{g}, 8.45^{\wedge \wedge} \mathrm{mmol}, 65^{\wedge \wedge}\right.$ equiv $), \mathrm{I}_{2}\left(0.066^{\wedge \wedge} \mathrm{g}\right.$,

$0.26^{\wedge \wedge} \mathrm{mmol}, 2^{\wedge \wedge}$ equiv), amine (45.5^^ $\mathrm{mmol}, 350^{\wedge \wedge}$ equiv), $\mathrm{C}_{2} \mathrm{H}_{4}\left(25^{\wedge \wedge} \mathrm{bar}\right.$, ca. $100^{\wedge \wedge} \mathrm{mmol}$, $770^{\wedge \wedge}$ equiv), $150^{\wedge} \mathrm{C}$. [b $]^{\wedge \wedge} N$-ethylaniline (1), $N, N$-diethylaniline (2), 2-methyl-quinoline (3), $N$-ethylmorpholine (4), $N$-ethylpiperidine (5), $N$-ethylbenzylamine (6), $N, N$ diethylbenzylamine (7). [c] $]^{\wedge \wedge} \mathrm{TON}_{1}$ or 4 or 5 or $\mathbf{6}+2 \mathrm{TON}_{2}$ or $7+2 \mathrm{TON}_{3}$.

Table $\mathrm{A}^{\wedge} 4<\mathrm{w}=1>$ Effect of the nature of the cation from the ionic liquid on the $\mathrm{RhCl}_{3} \cdot 3 \mathrm{H}_{2} \mathrm{O}$-catalysed hydroamination of ethylene by aniline. ${ }^{[\mathrm{a}]}$

\begin{tabular}{|c|c|c|c|c|c|c|c|}
\hline Entry & Ionic liquid ${ }^{\wedge \wedge}[$ equiv] & Ligand $^{\wedge \wedge}[$ equiv] & $\mathrm{I}_{2}^{\wedge \wedge}[$ equiv $]$ & $\mathrm{TON} \mathbf{1}^{[\mathrm{b}]}$ & TON $2^{[b]}$ & TON $3^{[b]}$ & $\mathrm{CE}^{[\mathrm{c}}$ \\
\hline 1 & $\mathrm{Ph}_{4} \mathrm{PI}(20)$ & -- & -- & 10 & 0 & 2 & 14 \\
\hline 2 & $\mathrm{Ph}_{4} \mathrm{PI}(65)$ & -- & -- & 16 & 0 & 0 & 16 \\
\hline 3 & $\mathrm{Ph}_{4} \mathrm{PI}(20)$ & $\mathrm{PPh}_{3}(2)$ & -- & 26 & 0 & 1 & 28 \\
\hline 4 & $\mathrm{Ph}_{4} \mathrm{PI}(65)$ & $\mathrm{PPh}_{3}(2)$ & -- & 27 & 0 & 0 & 27 \\
\hline 5 & $n \mathrm{Bu}_{4} \mathrm{NI}(65)$ & $\mathrm{PPh}_{3}(2)$ & 2 & 47 & 0 & 0 & 47 \\
\hline
\end{tabular}

[a] $]^{\wedge \wedge}$ Reaction conditions: $\mathrm{RhCl}_{3} \cdot 3 \mathrm{H}_{2} \mathrm{O}\left(34.2^{\wedge \wedge} \mathrm{mg}, 0.13^{\wedge \wedge} \mathrm{mmol}, 1^{\wedge \wedge}\right.$ equiv $), \mathrm{PPh}_{3}\left(68.2^{\wedge \wedge} \mathrm{mg}\right.$, $0.26^{\wedge \wedge} \mathrm{mmol}, 2^{\wedge \wedge}$ equiv $), \mathrm{I}_{2}\left(0.066^{\wedge \wedge} \mathrm{g}, 0.26^{\wedge \wedge} \mathrm{mmol}, 2^{\wedge \wedge}\right.$ equiv $)$, aniline $\left(4.1^{\wedge \wedge} \mathrm{mL}\right.$, $45.5^{\wedge \wedge} \mathrm{mmol}, 350^{\wedge \wedge}$ equiv), $\mathrm{C}_{2} \mathrm{H}_{4}\left(25^{\wedge \wedge}\right.$ bar, ca. ${ }^{\wedge \wedge} 100^{\wedge \wedge} \mathrm{mmol}, 770^{\wedge \wedge}$ equiv $), 96^{\wedge \wedge} \mathrm{h}, 150^{\wedge}{ }^{\circ} \mathrm{C}$. $[\mathrm{b}]^{\wedge \wedge} N$-ethylaniline (1), $N, N$-diethylaniline (2), 2-methyl-quinoline (3). [c $]^{\wedge \wedge} \mathrm{TON}_{1}+2 \mathrm{TON}_{2}$ $+2 \mathrm{TON}_{3}$.

Table^^5 $<\mathrm{w}=1>\mathrm{RhCl}_{3} \cdot 3 \mathrm{H}_{2} \mathrm{O}$-catalysed hydroamination of ethylene by aniline in the presence of an "in-situ" generated ionic liquid by one-pot addition of $\mathrm{PPh}_{3}$ and $\mathrm{I}_{2}$. ${ }^{\text {[a] }}$ 


\begin{tabular}{|l|c|l|l|l|l|l|}
\hline Entry & $\mathrm{PPh}_{3}{ }^{\wedge}[$ equiv] & $\mathrm{I}_{2}^{\wedge \wedge}[\wedge$ equiv] & TON 1 ${ }^{[\mathrm{b}]}$ & TON 2 $^{[\mathrm{b}]}$ & TON 3 $^{[\mathrm{b}]}$ & $\mathrm{CE}^{[\mathrm{c}]}$ \\
\hline 1 & $2<\mathrm{dp}>$ & $20<\mathrm{dp}>$ & $25<\mathrm{dp}>$ & $--<\mathrm{dp}>$ & $6<\mathrm{dp}>$ & $37<\mathrm{dp}>$ \\
\hline 2 & $5<\mathrm{dp}>$ & $5<\mathrm{dp}>$ & $94<\mathrm{dp}>$ & $6<\mathrm{dp}>$ & $--<\mathrm{dp}>$ & $106<\mathrm{dp}>$ \\
\hline 3 & $7<\mathrm{dp}>.5$ & $7<\mathrm{dp}>.5$ & $134<\mathrm{dp}>$ & $30<\mathrm{dp}>$ & $--<\mathrm{dp}>$ & $194<\mathrm{dp}>$ \\
\hline 4 & $10<\mathrm{dp}>$ & $10<\mathrm{dp}>$ & $21<\mathrm{dp}>$ & $189<\mathrm{dp}>$ & $--<\mathrm{dp}>$ & $399<\mathrm{dp}>$ \\
\hline 5 & $12<\mathrm{dp}>$ & $10<\mathrm{dp}>$ & $65<\mathrm{dp}>$ & $96<\mathrm{dp}>$ & $--<\mathrm{dp}>$ & $257<\mathrm{dp}>$ \\
\hline 6 & $20<\mathrm{dp}>$ & $20<\mathrm{dp}>$ & $23<\mathrm{dp}>$ & $139<\mathrm{dp}>$ & $--<\mathrm{dp}>$ & $301<\mathrm{dp}>$ \\
\hline 7 & $20<\mathrm{dp}>$ & $22<\mathrm{dp}>$ & $46<\mathrm{dp}>$ & $63<\mathrm{dp}>$ & $--<\mathrm{dp}>$ & $172<\mathrm{dp}>$ \\
\hline
\end{tabular}

[a] $]^{\wedge}$ Reaction conditions: $\mathrm{RhCl}_{3} \cdot 3 \mathrm{H}_{2} \mathrm{O}\left(34.2^{\wedge \wedge} \mathrm{mg}, 0.13^{\wedge \wedge} \mathrm{mmol}, 1^{\wedge \wedge}\right.$ equiv $), \mathrm{PPh}_{3}, \mathrm{I}_{2}$, aniline (4.1^^ $\mathrm{mL}, 45.5^{\wedge \wedge} \mathrm{mmol}, 350^{\wedge \wedge}$ equiv), $\mathrm{C}_{2} \mathrm{H}_{4}\left(25^{\wedge \wedge}\right.$ bar, ca. ${ }^{\wedge} 100^{\wedge \wedge} \mathrm{mmol}, 770^{\wedge \wedge}$ equiv $), 96^{\wedge \wedge} \mathrm{h}$, $150^{\wedge} \mathrm{C} .[\mathrm{b}]^{\wedge \wedge} N$-ethylaniline (1), $N, N$-diethylaniline (2), 2-methyl-quinoline (3). [c] ${ }^{\wedge \wedge} \mathrm{TON}_{1}+$ $2 \mathrm{TON}_{2}+2 \mathrm{TON}_{3}$

Table $\wedge^{\wedge} 6 \quad<w=1>$ Effect of reaction temperature and ethylene pressure on the $\mathrm{RhCl}_{3} \cdot 3 \mathrm{H}_{2} \mathrm{O}$-catalysed hydroamination of ethylene by aniline. ${ }^{[a]}$

\begin{tabular}{|l|l|l|l|l|l|l|}
\hline Entry & $T^{\wedge \wedge}\left[{ }^{\circ} \mathrm{C}\right]$ & $P^{\wedge \wedge}[\mathrm{bar}]$ & TON 1 & TON 2 & & TON 3 \\
\hline 1 & 150 & 25 & $114<\mathrm{dp}>$ & $114<\mathrm{dp}>$ & $7<\mathrm{dp}>$ & $355<\mathrm{dp}>$ \\
\hline 2 & 100 & 25 & $56<\mathrm{dp}>$ & $8<\mathrm{dp}>$ & $--<\mathrm{dp}>$ & $72<\mathrm{dp}>$ \\
\hline 3 & 100 & 45 & $30<\mathrm{dp}>$ & $2<\mathrm{dp}>$ & $3<\mathrm{dp}>$ & $40<\mathrm{dp}>$ \\
\hline 4 & 125 & 45 & $46<\mathrm{dp}>$ & $4<\mathrm{dp}>$ & $4<\mathrm{dp}>$ & $62<\mathrm{dp}>$ \\
\hline
\end{tabular}

[a] $]^{\wedge \wedge}$ Reaction conditions: $\mathrm{RhCl}_{3} \cdot 3 \mathrm{H}_{2} \mathrm{O}\left(34.2^{\wedge \wedge} \mathrm{mg}, 0.13^{\wedge \wedge} \mathrm{mmol}\right), \mathrm{PPh}_{3}\left(68.2^{\wedge \wedge} \mathrm{mg}\right.$ 0.26^^ mmol, $2^{\wedge \wedge}$ equiv), $n \mathrm{Bu}_{4} \mathrm{PI}\left(3.3^{\wedge \wedge} \mathrm{g}, 8.45^{\wedge \wedge} \mathrm{mmol}, 65^{\wedge \wedge}\right.$ equiv), $\mathrm{PhNH}_{2}\left(4.1^{\wedge \wedge} \mathrm{mL}\right.$, 
45.5^^ mmol, 350^^^equiv), $\mathrm{C}_{2} \mathrm{H}_{4}, 96^{\wedge \wedge} \mathrm{h}$. [b] $]^{\wedge \wedge} N$-ethylaniline (1), $N, N$-diethylaniline (2), 2 methyl-quinoline (3). [c] ${ }^{\wedge \wedge} \mathrm{TON}_{1}+2 \mathrm{TON}_{2}+2 \mathrm{TON}_{3}$.

Table ${ }^{\wedge \wedge} 7<\mathrm{w}=1>$ Effect of reaction time on the $\mathrm{RhCl}_{3} \cdot 3 \mathrm{H}_{2} \mathrm{O}$-catalysed hydroamination of ethylene by aniline. ${ }^{[a]}$

\begin{tabular}{|l|l|l|l|l|l|}
\hline Entry & $t^{\wedge \wedge}[\mathrm{h}]$ & TON 1 $^{[\mathrm{b}]}$ & TON 2 $^{[\mathrm{b}]}$ & TON 3 $^{[\mathrm{b}]}$ & EC $^{[\mathrm{c}]}$ \\
\hline 1 & 10 & 56 & $5<\mathrm{dp}>$ & 3 & $72<\mathrm{dp}>$ \\
\hline 2 & 93 & 28 & $225<\mathrm{dp}>$ & 3 & $484<\mathrm{dp}>$ \\
\hline
\end{tabular}

[a] ${ }^{\wedge \wedge}$ Reaction conditions: $\mathrm{RhCl}_{3} \cdot 3 \mathrm{H}_{2} \mathrm{O}\left(34.2^{\wedge \wedge} \mathrm{mg}, 0.13^{\wedge \wedge} \mathrm{mmol}\right), \mathrm{PPh}_{3}\left(68.2^{\wedge \wedge} \mathrm{mg}\right.$,

$0.26^{\wedge \wedge} \mathrm{mmol}, 2^{\wedge \wedge}$ equiv $), \mathrm{I}_{2}\left(0.066^{\wedge \wedge} \mathrm{g}, 0.26^{\wedge \wedge} \mathrm{mmol}, 2^{\wedge \wedge}\right.$ equiv $), n B u_{4} \mathrm{PI}\left(3.3^{\wedge \wedge} \mathrm{g}, 8.45^{\wedge \wedge} \mathrm{mmol}\right.$, 65^^equiv), $\mathrm{PhNH}_{2}\left(4.1^{\wedge \wedge} \mathrm{mL}, 45.5^{\wedge \wedge} \mathrm{mmol}, 350^{\wedge \wedge}\right.$ equiv $), \mathrm{C}_{2} \mathrm{H}_{4}\left(25^{\wedge \wedge}\right.$ bar, ca. ${ }^{\wedge \wedge} 100^{\wedge \wedge} \mathrm{mmol}$, $770^{\wedge \wedge}$ equiv), $150^{\wedge} \mathrm{C}$. [b] $]^{\wedge \wedge} N$-ethylaniline (1), $N, N$-diethylaniline (2), 2-methyl-quinoline (3). $[\mathrm{c}]^{\wedge \wedge} \mathrm{TON}_{1}+2 \mathrm{TON}_{2}+2 \mathrm{TON}_{3}$.

Table $\mathrm{A}^{\wedge} 8<\mathrm{w}=1>$ Hydroamination of 1-butene by aniline catalysed by the $\mathrm{RhCl}_{3} \cdot 3 \mathrm{H}_{2} \mathrm{O} / \mathrm{PPh}_{3}$ system. $^{\text {[a] }}$

\begin{tabular}{|c|c|c|c|c|c|}
\hline Entry & Ligand & Salt ${ }^{\wedge \wedge}$ [equiv] & $\mathrm{I}_{2}^{\wedge \wedge}$ [equiv] & TON & $\mathrm{M} / \mathrm{AM}^{[\mathrm{b}]}$ \\
\hline 1 & -- & -- & $--<d p>$ & $1<\mathrm{dp}>$ & n.d. \\
\hline 2 & -- & $n \mathrm{Bu}_{4} \mathrm{PBr}(65)$ & $--\langle\mathrm{dp}\rangle$ & $18<\mathrm{dp}>$ & $99: 1$ \\
\hline 3 & -- & $n \mathrm{Bu}_{4} \mathrm{PI}(65)$ & $--\langle d p\rangle$ & $74<\mathrm{dp}>$ & 99:1 \\
\hline 4 & $\mathrm{PPh}_{3}$ & -- & $2\langle\mathrm{dp}\rangle$ & $23<\mathrm{dp}>$ & 99:1 \\
\hline 5 & $\mathrm{PPh}_{3}$ & $n \mathrm{Bu}_{4} \mathrm{PI}(65)$ & $--\langle d p>$ & $86<d p>$ & $99: 1$ \\
\hline 6 & $\mathrm{PPh}_{3}$ & $n \mathrm{Bu}_{4} \mathrm{PI}(65)$ & $2\langle\mathrm{dp}\rangle$ & $153<\mathrm{dp}>$ & 99:1 \\
\hline 7 & $\mathrm{PPh}_{3}$ & $n \mathrm{Bu}_{4} \mathrm{PI}(150)$ & $2<\mathrm{dp}>$ & $133<d p>$ & 99:1 \\
\hline
\end{tabular}


[a] ${ }^{\wedge \wedge}$ Reaction conditions: $\mathrm{RhCl}_{3} \cdot 3 \mathrm{H}_{2} \mathrm{O}\left(34.2^{\wedge \wedge} \mathrm{mg}, 0.13^{\wedge \wedge} \mathrm{mmol}\right), \mathrm{PPh}_{3}\left(68.2^{\wedge \wedge} \mathrm{mg}\right.$,

0.26^^ mmol, $2^{\wedge \wedge}$ equiv), $n \mathrm{Bu}_{4} \mathrm{PBr}$ or $n \mathrm{Bu}_{4} \mathrm{PI}, \mathrm{PhNH}_{2}\left(4.1^{\wedge \wedge} \mathrm{mL}, 45.5^{\wedge \wedge} \mathrm{mmol}, 350^{\wedge \wedge}\right.$ equiv), $\mathrm{I}_{2}$,

1-butene $\left(8.9^{\wedge \wedge} \mathrm{mL}, 100^{\wedge \wedge} \mathrm{mmol}\right.$, ca. ${ }^{\wedge \wedge} 770^{\wedge \wedge}$ equiv $), 150^{\wedge} \mathrm{C}, 96^{\wedge \wedge} \mathrm{h} .[\mathrm{b}]^{\wedge \wedge}$ Ratio of

Markovnikov (M) and anti-Markovnikov (AM) isomers. n.d.=not determined.

Table ${ }^{\wedge \wedge 9}<\mathrm{w}=1>$ Hydroamination of 1-hexene by aniline catalysed by

$\mathrm{RhCl}_{3} \cdot 3 \mathrm{H}_{2} \mathrm{O} / \mathrm{PPh}_{3}$. ${ }^{[\mathrm{a}]}$

\begin{tabular}{|l|l|l|l|l|l|l|}
\hline Entry & Catalyst & Salt^^[equiv] & Ligand $^{\wedge \wedge}[$ equiv] & $t^{\wedge \wedge}[\mathrm{h}]$ & $\mathrm{TON}$ & ${\mathrm{M} / \mathrm{AM}^{[\mathrm{b}]}}$ \\
\hline 1 & $\mathrm{PtBr}_{2}$ & $n \mathrm{Bu}_{4} \mathrm{PI}(65)$ & -- & 10 & $6<\mathrm{dp}>$ & $95<\mathrm{dp}>: 5$ \\
\hline 2 & $\mathrm{RhCl}_{3} \cdot 3 \mathrm{H}_{2} \mathrm{O}$ & $n \mathrm{Bu}_{4} \mathrm{PI}(150)$ & $\mathrm{PPh}_{3}(2)$ & 96 & $56<\mathrm{dp}>$ & $100<\mathrm{dp}>: 0$ \\
\hline 3 & $\mathrm{RhCl}_{3} \cdot 3 \mathrm{H}_{2} \mathrm{O}$ & -- & $\mathrm{PPh}_{3}(2)$ & 96 & $1<\mathrm{dp}>$ & $100<\mathrm{dp}>: 0$ \\
\hline
\end{tabular}

[a] $]^{\wedge \wedge}$ Reaction conditions: $\mathrm{RhCl}_{3} \cdot 3 \mathrm{H}_{2} \mathrm{O}\left(34.2^{\wedge \wedge} \mathrm{mg}, 0.13^{\wedge \wedge} \mathrm{mmol}\right), \mathrm{PPh}_{3}\left(68.2^{\wedge \wedge} \mathrm{mg}\right.$,

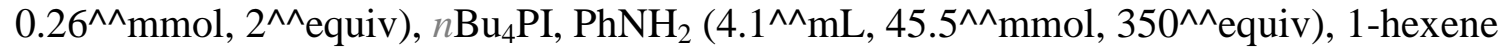

$\left(11.3^{\wedge \wedge} \mathrm{mL}, 91^{\wedge \wedge} \mathrm{mmol}, \mathrm{ca} \cdot{ }^{\wedge \wedge} 770^{\wedge \wedge}\right.$ equiv $), 150^{\wedge}{ }^{\circ} \mathrm{C} .[\mathrm{b}]^{\wedge \wedge}$ Ratio of Markovnikov $(\mathrm{M})$ and anti-

Markovnikov (AM) isomers.

Table ${ }^{\wedge \wedge} 10<\mathrm{w}=1>$ Hydroamination of ethylene by aniline catalysed by $\mathrm{Rh}^{\mathrm{I}}$ complexes. ${ }^{[\mathrm{a}]}$

\begin{tabular}{|l|l|l|l|l|l|}
\hline Entry & Catalyst & TON 1 & TON 2 & TON 3 & EC \\
\hline 1 & {$\left[\mathrm{RhCl}\left(\mathrm{PPh}_{3}\right)_{3}\right]$} & 122 & $126<\mathrm{dp}>$ & -- & 374 \\
\hline 2 & {$\left[\mathrm{RhCl}\left(\mathrm{PPh}_{3}\right)_{2}\right]_{2}$} & 129 & $73<\mathrm{dp}>$ & -- & 275 \\
\hline
\end{tabular}

[a] $]^{\wedge \wedge}$ Reaction conditions: $\mathrm{Rh}^{\mathrm{I}}\left(0.13^{\wedge \wedge} \mathrm{mmol}\right), \mathrm{I}_{2}\left(0.066^{\wedge \wedge} \mathrm{g}, 0.26^{\wedge \wedge} \mathrm{mmol}, 2^{\wedge \wedge}\right.$ equiv $), n \mathrm{Bu}_{4} \mathrm{PI}$ (3.3^^ $\mathrm{g}, 8.45^{\wedge \wedge} \mathrm{mmol}, 65^{\wedge \wedge}$ equiv), $\mathrm{PhNH}_{2}\left(4.1^{\wedge \wedge} \mathrm{mL}, 45.5^{\wedge \wedge} \mathrm{mmol}, 350^{\wedge \wedge}\right.$ equiv), $\mathrm{C}_{2} \mathrm{H}_{4}$ $\left(25^{\wedge \wedge} \text { bar, ca. }{ }^{\wedge} 100^{\wedge \wedge} \mathrm{mmol}, 770^{\wedge \wedge} \text { equiv), } 150^{\wedge} \mathrm{C}, 96^{\wedge \wedge} \mathrm{h} \text {. [b] }\right]^{\wedge \wedge} N$-ethylaniline $(\mathbf{1}), N, N-$ diethylaniline (2), 2-methyl-quinoline (3). [c] $]^{\wedge \wedge} \mathrm{TON}_{1}+2 \mathrm{TON}_{2}+2 \mathrm{TON}_{3}$. 